Case study

\title{
The Energy, Economic and Environmental Efficiency of a PV Installation Cooperating with a Heat Pump in the Central Part of Europe. Case study
}

\author{
Sylwia Wciślik ${ }^{1 *}$, Dagmara Kotrys-Działak ${ }^{2}$ \\ 1 Department of Piped Utility Systems, Faculty of Environmental, Geomatic and Energy Engineering, Kielce \\ University of Technology, Aleja Tysiaclecia Panstwa Polskiego 7, 25-314 Kielce, Poland; \\ sylwiazw@tu.kielce.pl \\ 2 Department of Piped Utility Systems, Faculty of Environmental, Geomatic and Energy Engineering, Kielce \\ University of Technology, Aleja Tysiaclecia Panstwa Polskiego 7, 25-314 Kielce, Poland; \\ ddzialak@tu.kielce.pl \\ * Correspondence: sylwiazw@tu.kielce.pl, +48 413424829
}

\begin{abstract}
The paper addresses an analysis of the efficiency and profitability of the operation of a photovoltaic installation located in the geometric centre of Europe (near Białystok, Poland), where the intensity of solar irradiation is not too high compared to other European countries. It is calculated that in that place average solar irradiation being lower even by approx. $26 \mathrm{kWh}$ than that for the whole Europe, which results in a $26 \%$ drop in the economic potential of the utilisation of solar energy for its conversion. A case study and an economic analysis show that without minimum funding amounting to $50 \%$ of the investment costs paid for the modernisation of a central heating system assisted by PV cells, the time of return of pecuniary expenditures exceeds 7 years. Apart from the Simple Pay-Back Time SPBT, discount indicators determined in the paper also include the net present value NPV and the internal rate of return IRR. Moreover, a direct ecological effect has been determined for such an investment.
\end{abstract}

Keywords: environmental efficiency; energy; economic; PV installation; modernization; economic analysis; ecological effect,

\section{Introduction}

When searching for efficient techniques increasing the energy potential related to the conversion of pure energy originating from the Sun [1] - a spectral type G star, attempts are made to utilise it both by means of direct - helioelectric, as well as indirect methods, related to heat transfer [2], meaning heliothermal. Due to this, the commissioning of installations with photovoltaic cells with increasingly larger areas and higher powers seems to be a reasonable trend [3]. Such an action also follows one of the main objectives of the amended EU directive related to the energy characteristics of buildings [4], meaning the reduction of the emission of greenhouse gases until 2050 by $80-95 \%$ compared to 1990. In the long term, it will enable conversion of existing buildings into buildings with an almost zero energy consumption - for which the ratio of demand for nonrenewable primary energy EP is close to $0 \mathrm{kWh} /\left(\mathrm{m}^{2}\right.$ year $)$. A solution to this involves an increase in the scale of complex and deep thermal upgrading, as well as the construction of new facilities with a low emission of $\mathrm{CO}_{2}$ and particulate matter, PM.

The term deep thermal upgrading is to be understood as reaching such an energy standard of a building after thermal upgrading, which would fulfil requirements related to energy efficiency like those for new buildings, and, e.g. this standard for residential single-family and multi-family buildings expressed by the ratio of demand for nonrenewable primary energy for the needs of heating, ventilation and the preparation of warm utility water amounts to $E P \max , \mathrm{H+w}=70$ and 65 $\mathrm{kWh} /\left(\mathrm{m}^{2}\right.$ year), respectively; educational buildings: $\quad \mathrm{EP}_{\max , \mathrm{H}+\mathrm{w}}=190 \mathrm{kWh} /\left(\mathrm{m}^{2}\right.$ year) (status for Poland 
- the geometric centre of Europe - as of 1 January 2021). The remaining member states with a longer membership in the European Union are under an obligation to make the energy standards of buildings erected starting from 2021 similar to those of zero-energy buildings.

Poland should have implemented the provisions of Directive [4] by 10 March 2020. Meanwhile, only $1 \%$ of single-family buildings in Poland are energy efficient, meaning that the ratio of demand for nonrenewable primary energy $E P_{\max }=95 \mathrm{kWh} / \mathrm{m}^{2}$ year (starting from 2021, $E P_{\max }=70 \mathrm{kWh} / \mathrm{m}^{2}$ year), and almost $70 \%$ are heated using black coal and require modernisation.

European law [5] encourages the use of renewable energy sources, but an analysis of the profitability of their utilisation often indicates the lack of viability. Due to this, there is an observed increase in the number of submitted applications for the funding of actions related to thermal upgrading, the assembly of RES installations and the auditing of energy and energy efficiency.

Belgium is among the countries which during the last 5 years saw a considerable increase in powers resulting from the installed PV cells [6].

A review of government measures which influenced both the exponential increase in new PV systems, as well as their stagnation between 2006 and 2013, is discussed in [6].

The report [3] also indicates that the combined power installed in photovoltaic sources in Poland amounted to approx. $1500 \mathrm{MW}$ as of the end of 2019 (three times more than in 2018), while in May 2020 it exceeded 1950 MW (an increase by almost 30\% was recorded compared to 2019). In 2019, Poland was rated fifth among EU countries, due to a yearly power increase of $0.9 \mathrm{GW}$ (i.e. almost $40 \%$ of annual growth). It is predicted that in mid-2020 Poland will be rated 4th among EU countries in terms of new installed power. [3] predicts that even $1 \mathrm{GW}$ of new PV installations will be added in the whole year 2020, and the total power of photovoltaic installations in Poland at the end of 2020 will amount to $2.5 \mathrm{GW}$.

Among European countries, the highest increase in new PV power in 2018 was recorded in Germany (over $3 \mathrm{GW}$ ), the Netherlands (1.5 GW), France (1.3 GW) and Hungary (over 0.5 GW); these are followed by Italy, Spain, Greece and Czechia [7]. No dynamic increase in the installations and power originating from photovoltaics in Europe was recorded until 2018 (over 50\% more new PV installations compared to 2017 [7]), after 6 years of lowering annual increases, although the RES Directive [8] was introduced already in 2009.

An analysis of the operation of over 31,000 PV systems installed in Europe between 2006 and 2014 indicates that it is difficult to determine their capacity unambiguously [9] due to the significant difference in the efficiency of the inverters and modules themselves, as well as the technology of their production. There are estimates of an even $30 \%$ difference in the efficiency of the system, resulting from the quality of production of the modules themselves.

In order to assess the capacity of a PV system, the so-called PR ratio is determined, which measures the difference between the real and theoretical production of energy by a photovoltaic system, expressed as percentage of energy generated by a system relative to potential energy calculated by measuring the intensity of solar irradiation and temperature [10]. Over seven years, the recorded improvement in the annual increase in the PR ratio amounted to approximately $0.5 \%$. The desired unit performance ratio PR for new installations is 0.84 . When reached, such a value would influence an improvement in the capacity of PV systems by approximately $10 \%$ and the same level of reduction in the cost of consumption of electricity [9].

For quick assessment of the ability to use the energy of solar irradiation for a given region in the world, country or town, it is possible to implement physical and mathematical models used to perform simulations of the efficiency of solar cells into the computer environment. In here, attention should be paid to the fact that solar irradiation which reaches the surface of an absorber located on the ground is weakened by Earth's atmosphere and other phenomena, such as scattering, reflection or attenuation (see sketch of the anisotropic solar irradiation model in Figure 1).

Relatively fast, simple and most popular radiative transfer models (RTMs), taking into account, e.g. atmospheric transmission vs wavelength, Rayleigh scattering, aerosol scattering, water vapour absorption, ozone absorption, unmixed gas absorption, turbidity, precipitable water vapour, EarthSun factor, include: the Simple Model of the Atmospheric Radiative Transfer of Sunshine (SMART) with an uncertainty range of up to $5 \div 10 \%$ [11] and the Model of American Society for Testing and 
Materials (ASTM). Moreover, the following models are also known: Second Simulation of a Satellite Signal in the Solar Spectrum (6S) [12], SCIATRAN [13], SHARM [14], RT3 [15], RTMOM [16], RAY [17], STAR [18], Pstar2 [19], DISORT [20], along with computer programs which use them: MODTRAN [21], STREAMER [22] and SBDART [23], PV Lighthouse, SMART [24], SOLAR GIS, Solar CalQ 1.0 and others.

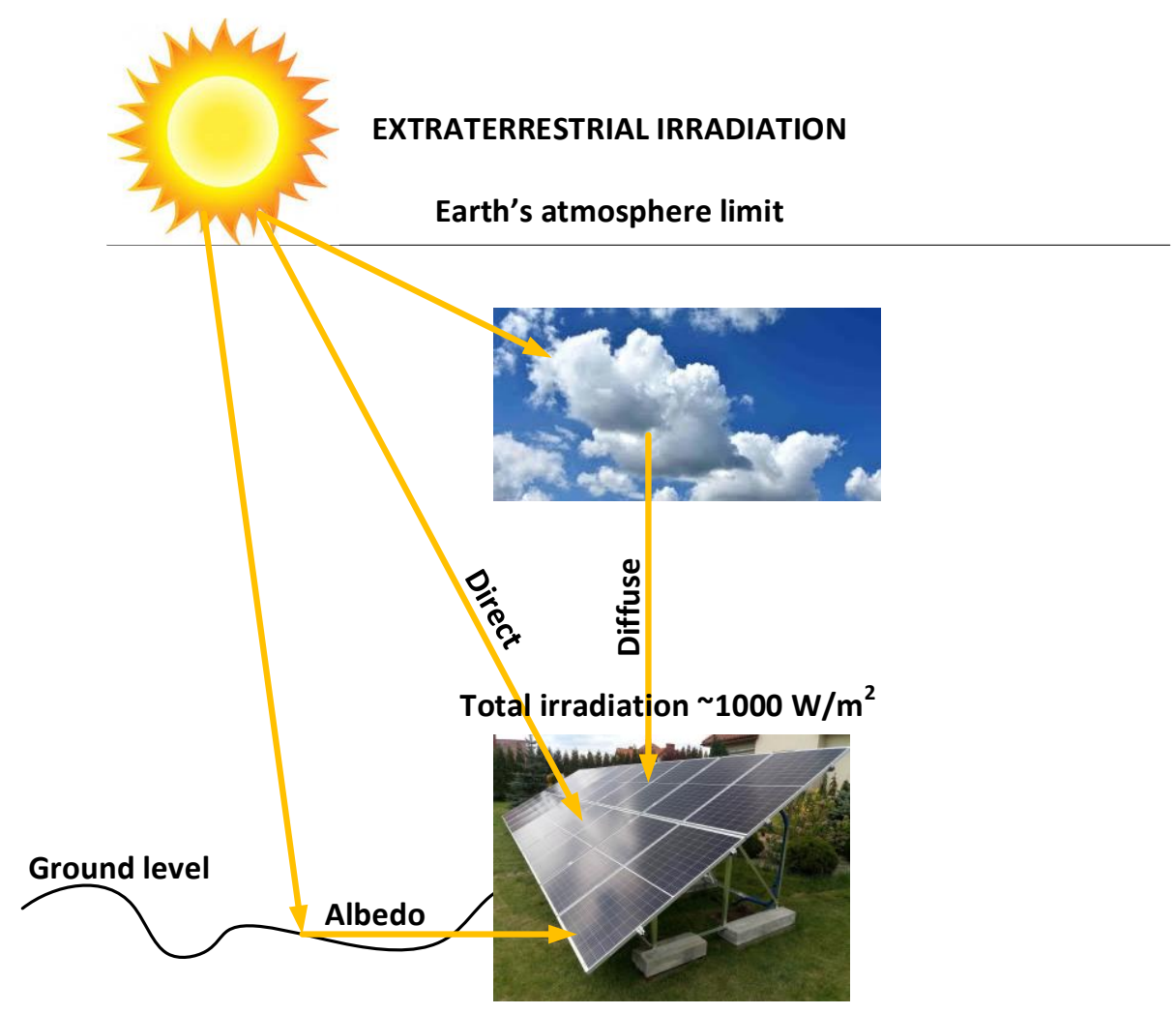

Figure 1. Sketch of the anisotropic solar irradiation model.

The present paper analyses the energy, environmental and economic efficiency of a sample photovoltaic installation located in the geometric centre of Europe (near Białystok, Poland), where the intensity of solar irradiation is not too high compared to other European countries [25]. Currently, one of the basic requirements faced by buildings undergoing modernisation involves limitation in the emission of carbon dioxide even by over $90 \%$ compared to original values. In order to fulfil these criteria, it is necessary to use alternative solutions based on renewable energy sources. In here, photovoltaics constitutes a reasonable option and provides the possibility to achieve a high level of reduction in the emission of primary contaminants, such as $\mathrm{CO}_{2}, \mathrm{SO}_{x}, \mathrm{NO}_{x}$ or solid particles.

European law $[3-5,8]$ encourages the use of renewable energy sources, but an analysis of the profitability of their utilisation indicates the lack of feasibility, which is decided primarily by the location, as confirmed by economic efficiency indicators calculated for a sample investment, such as the Simple Pay-Back Time SPBT, the net present value NPV and the internal rate of return IRR.

Moreover, the paper presents a comparative analysis for the potential of utilising solar energy in European countries with extreme values of total average intensity of solar irradiation.

\section{Solar Irradiation Density in Europe.}

It turns out that, according to the calculations of Szymon Antonii Sobiekrajski of 1775, the geometric centre of Europe is located in north-eastern Poland, in Suchowola near Białystok. According to statistical data originating from a weather station in this area, developed based on full 30-year measurement cycles used for energy balances of buildings, the sum of total intensity of solar irradiation incident on a horizontal plane amounts to ITHav,year $=897.14 \mathrm{kWh} / \mathrm{m}^{2}$ (the monthly average 


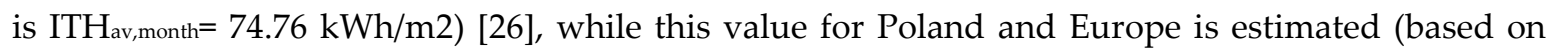
interpolation and modelling of 580 meteorological measurements constituting a database for a period of $1981-1990)$ at $1012 \mathrm{kWh} / \mathrm{m}^{2}\left(\mathrm{ITH}_{\mathrm{av}, \text { month }}=84.33 \mathrm{kWh} / \mathrm{m} 2\right)$ and $1205 \mathrm{kWh} / \mathrm{m} 2\left(\mathrm{ITH}_{\mathrm{av}, \text { month }}=100.42\right.$ $\left.\mathrm{kWh} / \mathrm{m}^{2}\right)$, respectively $[27,28]$. The highest and lowest values of total intensity ITHav,year are recorded in Malta and Finland and they amount to $1766 \mathrm{kWh} / \mathrm{m}^{2}$ and $841 \mathrm{kWh} / \mathrm{m}^{2}$, respectively. The distribution of direct average annual solar irradiation in Poland and European countries is mapped and updated in the Solar GIS base in an ongoing manner [29]. The Solar GIS database has been validated at 200+ locations globally. A long historical archive of solar irradiation data is available for any location between latitudes of $60 \mathrm{~N}$ and $45 \mathrm{~S}$.

Figure 2 presents a general map of the distribution of total annual average solar irradiation for Poland and for European countries.

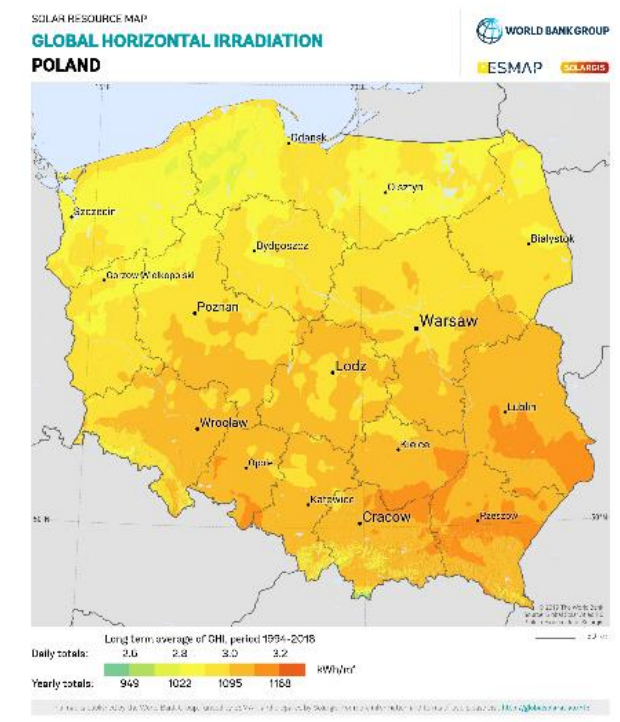

(a)

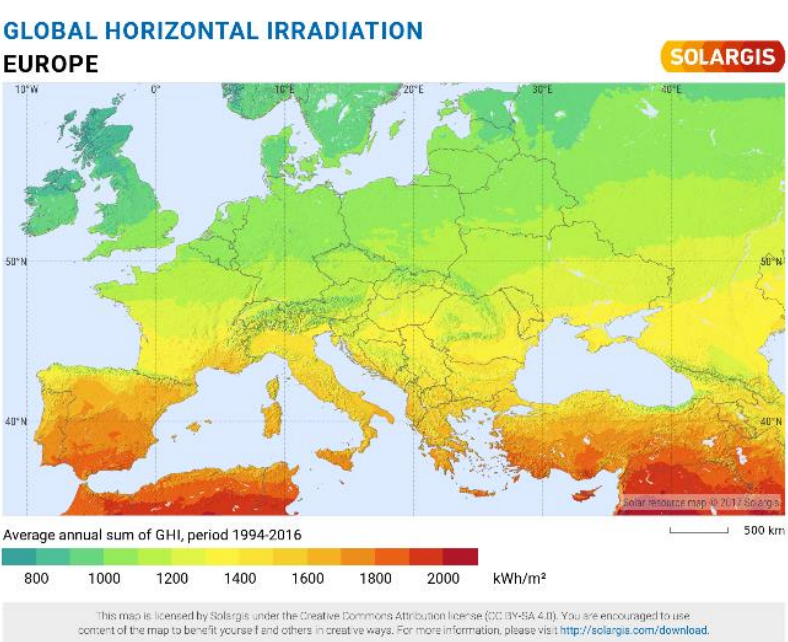

(b)

Figure 2. Map of total solar irradiation in (a) Poland and in (b) Europe [7].

Graph 3 presents the monthly distribution of total solar irradiation intensity for the geometric centre of Europe - a spot near Białystok, which indicates that the monthly average solar irradiation intensity for the geometric centre of Europe is lower by approx. $26 \mathrm{kWh}$ than the European average, which results in a $26 \%$ reduction in the economic potential of utilisation of solar energy for the purpose of its conversion. Compared to conditions in the country, this amounts to $11 \%$.

Additionally, Figure 4 shows a climograph representing countries with extreme values of the dry-bulb temperature, MDBT, which is compared to the ITH value for the geometric centre of Europe.

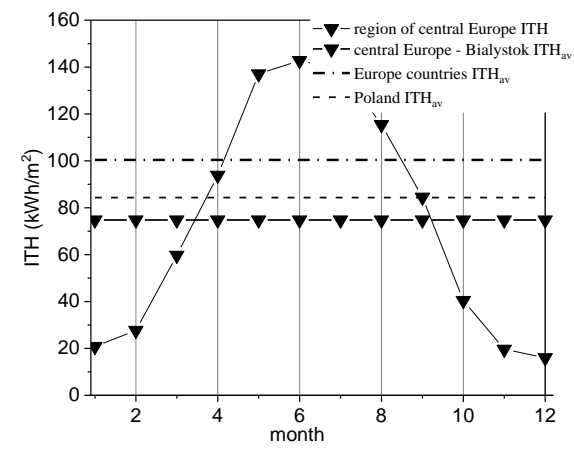

Figure 3. Solar irradiation density for the centre of Europe.

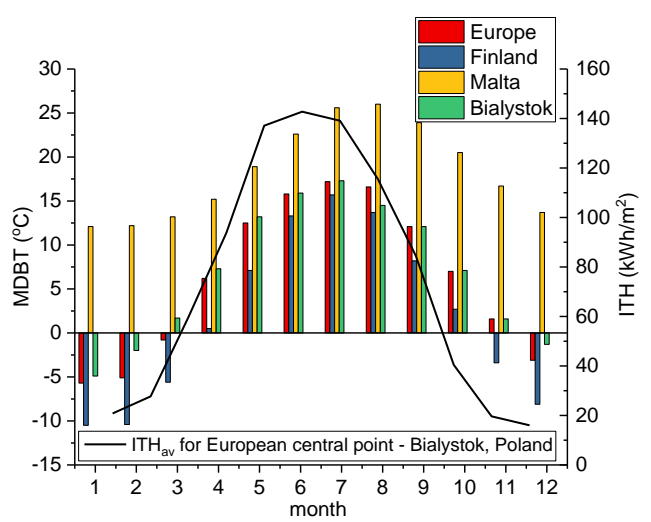

Figure 4. A climograph for selected European countries. 
Graph 5 in turn presents average ITH values recorded by the Photovoltaic Geographical Information System (PVGIS) for European Communities in the years 2001 - 2019, which indicate that Poland is rated twentieth in terms of the conditions of insolation, and the ITH in here is lower by $16 \%$ and $43 \%$ than European average and the maximum average for Malta, respectively, and higher by $17 \%$ than the minimum average recorded for Finland.

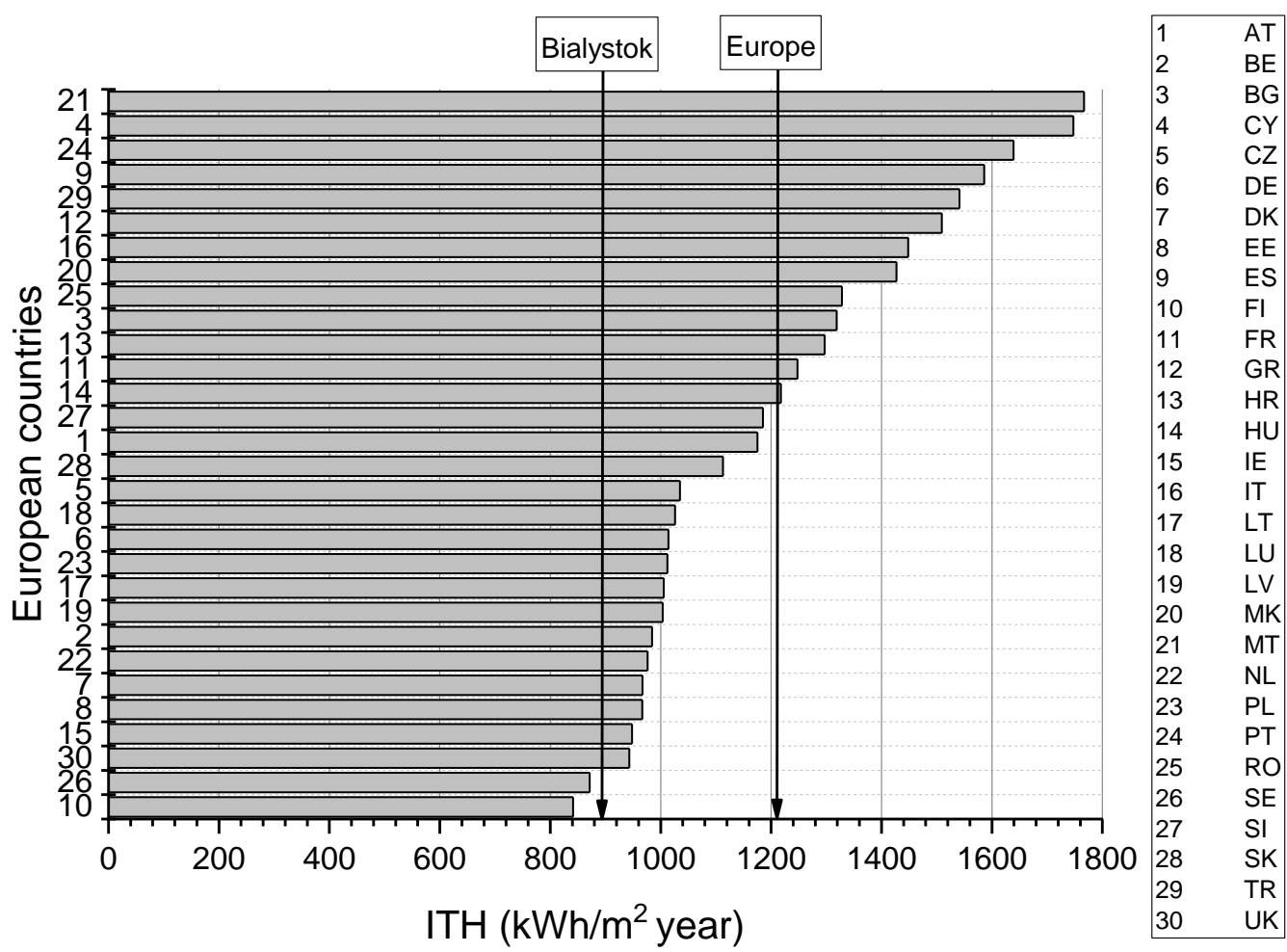

Figure 5. Total average intensity of solar irradiation on the horizontal plane for European countries (Global yearly irradiation); 1-AT- Austria, 2-BE- Belgium, 3-BG- Bulgaria, 4-CY-Cyprus, 5-CZ- Czech Republic, 6-DEGermany, 7-DK- Denmark, 8-EE- Estonia, 9-ES- Spain, 10-FI- Finland, 10-FR- France, 11-GR- Greece, 12-HRCroatia, 13-HU- Hungary, 14-IE- Ireland, 15-IT- Italy, 16-LT- Lithuania, 17-LU- Luxembourg, 18-LV- Latvia, 19MK- Republic of North Macedonia, 20-MT- Malta, 21-NL- Netherlands, 22-PL- Poland, 23-PT- Portugal, 24-RORomania, 25-SE- Sweden, 26-SI- Slovenia, 27-SK- Slovakia, 28-TR- Turkey, 29- UK- United Kingdom.

For the highest possible utilisation of the energy potential of PV panels, it is suggested to optimise their tilt angle, or additionally to commission a tracking installation [30,31]; the 18-year average optimal angle of the position of photovoltaic panels for Poland amounts to approx. $36^{\circ}$, with $32^{\circ}$ for Malta and even $45^{\circ}$ for Finland (see Figure 6). 


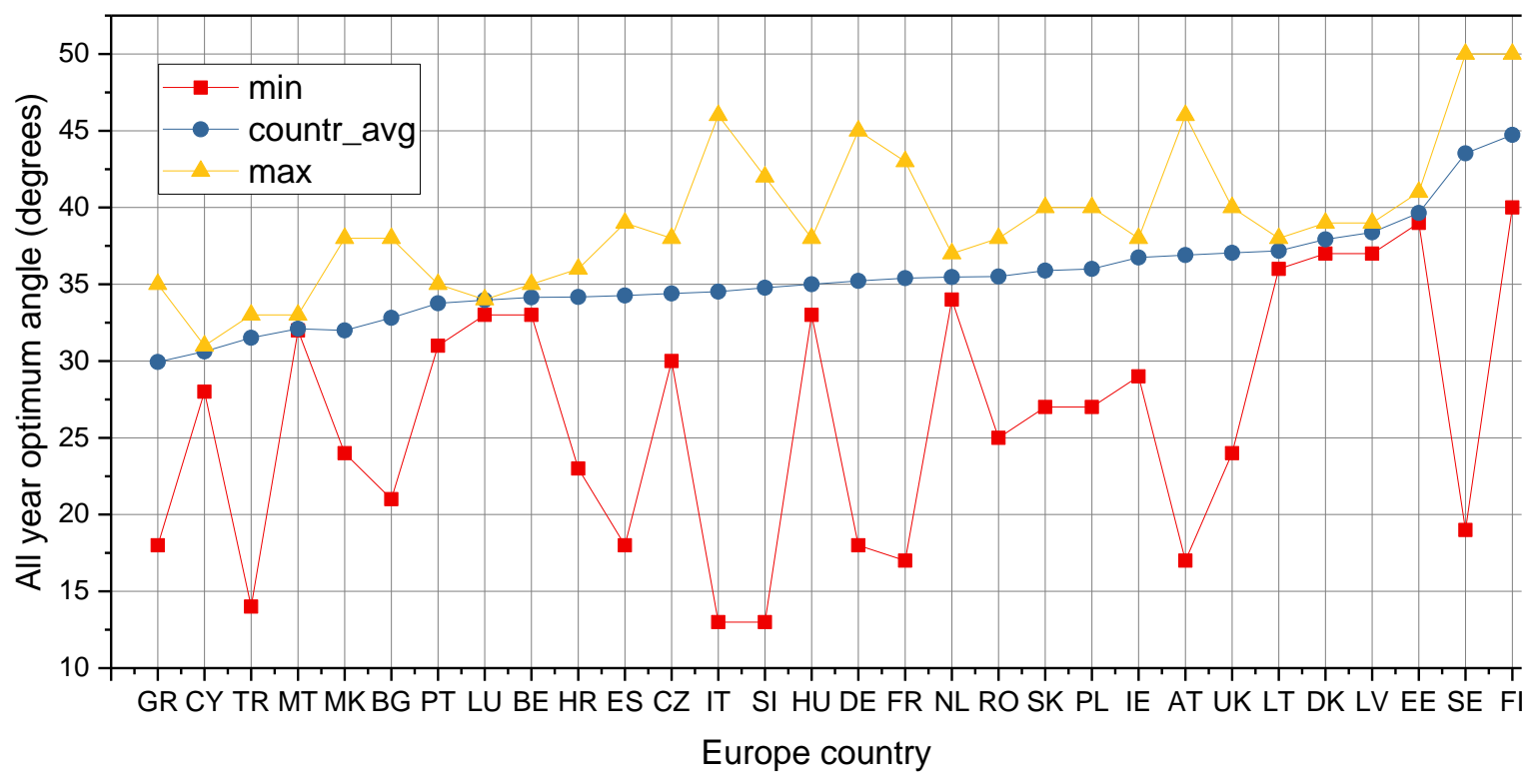

Figure 6. The optimal tilt angle of photovoltaic panels (an average of 18 years) aimed at the utilisation of their maximum capacity

\section{The Simple Model of the Atmospheric Radiative Transfer of Sunshine}

The assessment of average solar conditions existing in Europe was performed using version 1.1.1 of the PV Lighthouse calculator, operable since 2011 and continuously reviewed, updated with current information on insolation, modernised, e.g. by Keith McIntosh, Malcolm Abbott, Ben Sudbury and other specialists in the field. Figure 7 presents a conceptual map of physical models used by PV Lighthouse calculators.

\section{CALCULATOR MAP}

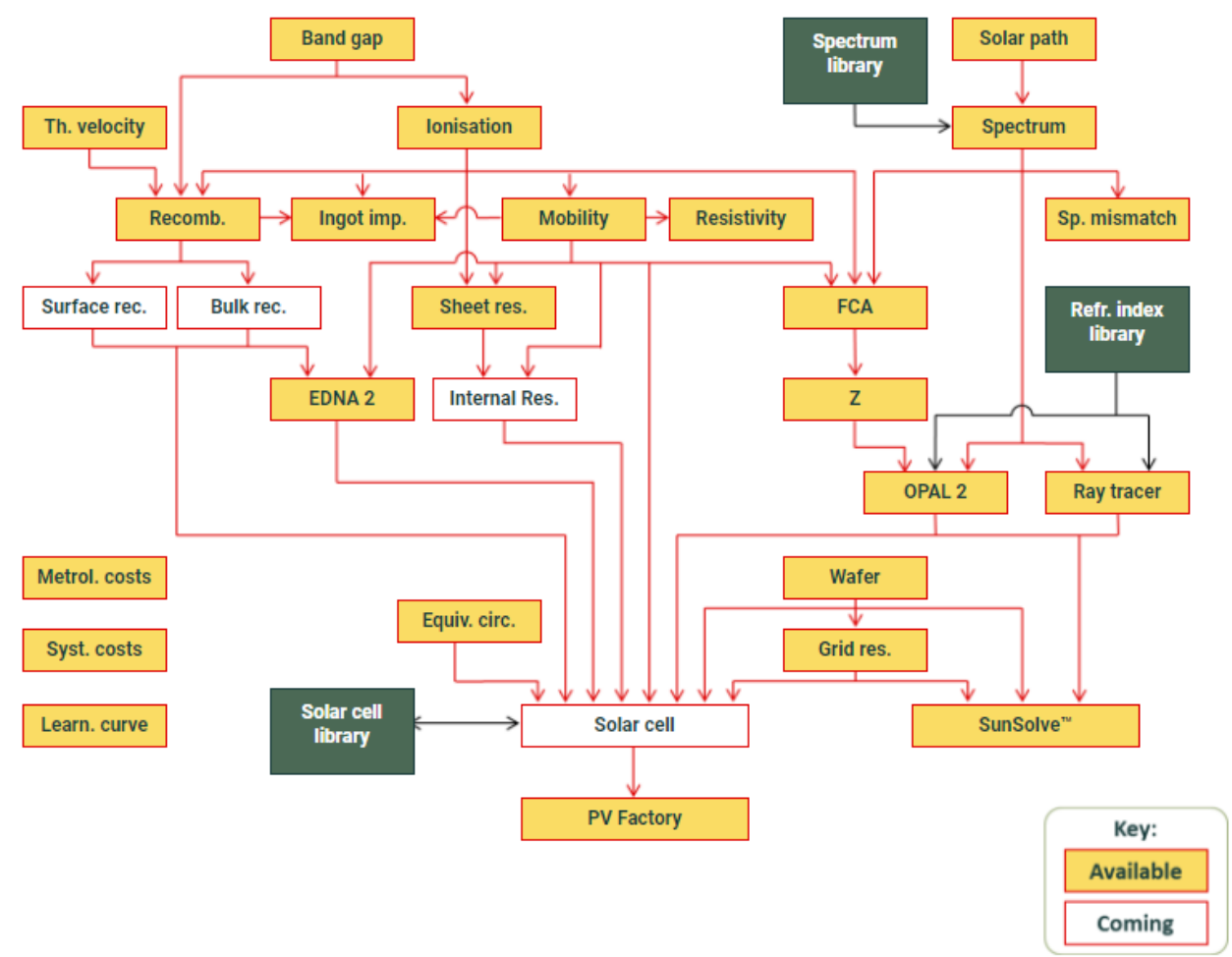


Figure 7. Conceptual map of physical models used by PV Lighthouse calculators [32].

Simulations were performed for the central part of Europe - an area near Białystok (Poland), the capitals of Malta - Valletta and Finland - Helsinki, for which the respective values of total average intensity of solar irradiation on the horizontal plane were the highest and the lowest. Special attention should be paid to Finland, for which, due to locational aspects, the conditions of insolation were also estimated in the city of Rovaniemi, situated in the Arctic Circle. The input data and sample results of the performed simulations of spectral irradiance (extraterrestrial, direct, diffuse, global) vs wavelength incident on the module, horizontal and perpendicular, are listed in Table 1 and on $x-y$ graphs. The tilt angle varying among countries results from the optimisation of the positioning of solar panels aimed at the utilisation of their maximum capacity (see Figure 6).

Table 1. General and atmospheric input and output data for simulations using the PV Lighthouse calculator

\begin{tabular}{|c|c|c|c|c|}
\hline \multicolumn{5}{|c|}{ Inputs } \\
\hline Country & Poland & Malta & \multicolumn{2}{|c|}{ Finland } \\
\hline City & Białystok & Valletta & Helsinki & Rovaniemi \\
\hline Longitude & $23.1643300^{\circ}$ & $14.5147200^{\circ}$ & $24.9354500^{\circ}$ & $25.7166700^{\circ}$ \\
\hline Latitude & $53.1333300^{\circ}$ & $35.8997200^{\circ}$ & $60.1695200^{\circ}$ & $66.5000000^{\circ}$ \\
\hline Albedo & \multicolumn{3}{|c|}{0.3} & \\
\hline Tilt angle & $36^{\circ}$ & $32^{\circ}$ & \multicolumn{2}{|r|}{$45^{\circ}$} \\
\hline Azimuth angle & \multicolumn{4}{|c|}{$180^{\circ}$} \\
\hline Earth-Sun factor & \multicolumn{4}{|c|}{0.967} \\
\hline $\begin{array}{l}\text { Atmospheric } \\
\text { pressure, mbar }\end{array}$ & \multicolumn{4}{|c|}{1013.25} \\
\hline Turbidity at $500, \mathrm{~nm}$ : & \multicolumn{4}{|c|}{0.084} \\
\hline $\begin{array}{l}\text { Precipitable water } \\
\text { vapour, } \mathrm{cm}\end{array}$ & \multicolumn{4}{|c|}{1.4164} \\
\hline Ozone, atm-cm & \multicolumn{4}{|c|}{0.3438} \\
\hline Incident spectrum & \multicolumn{4}{|c|}{$\begin{array}{l}\text { AM0 [Gue95] - the Air Mass } 0 \text { spectrum, generated with } \\
\text { SMARTS v 2.9.2 (with the SMARTS/Gueymard model } \\
\text { chosen for the extraterrestrial spectrum) }\end{array}$} \\
\hline Transmission model & \multicolumn{4}{|c|}{ SPCTRAL2 [Bir86] [33] } \\
\hline \multicolumn{5}{|c|}{ Outputs } \\
\hline \multicolumn{5}{|c|}{ Insolation; solar position } \\
\hline Date and hour & \multicolumn{3}{|c|}{$15-07-2019 ; 12: 00$} & \\
\hline Air mass & 1.18 & 1.03 & 1.28 & 1.42 \\
\hline Zenith angle, & $31.86^{\circ}$ & 14.73 & 38.95 & 45.27 \\
\hline Azimuth angle & $177.30^{\circ}$ & 174.38 & 177.73 & 177.99 \\
\hline Incident angle & $4.41^{\circ}$ & 18.40 & 6.24 & 1.45 \\
\hline \multicolumn{5}{|c|}{$\begin{array}{l}\text { Spectral irradiance vs wavelength incident to perpendicular, horizontal and into } \\
\text { module plane, W/m2/nm: see Fig. } 8,9,10,13\end{array}$} \\
\hline \multirow{2}{*}{\multicolumn{5}{|c|}{$\begin{array}{l}\text { Power density (perpendicular and into module location) }(\mathrm{W} / \mathrm{m} 2) \text { : see Figure } 14 \\
\text { Photon current (perpendicular and into module location) }(\mathrm{mA} / \mathrm{cm} 2) \text { : see Figure } \\
15\end{array}$}} \\
\hline & & & & \\
\hline \multicolumn{5}{|c|}{ Atmospheric transmission vs wavelength: see Figure 11} \\
\hline Date and hour & \multicolumn{3}{|c|}{ 01-01-2019; $12: 00$} & \\
\hline Air mass & 4.16 & 1.93 & 8.37 & 107.55 \\
\hline Zenith angle, & 76.13 & 58.90 & 83.17 & 89.50 \\
\hline Azimuth angle & 179.17 & 179.06 & 179.19 & 179.20 \\
\hline
\end{tabular}




\begin{tabular}{|l|l|r|r|r|}
\hline Incident angle & 40.14 & 26.90 & 38.17 & 44.50 \\
\hline
\end{tabular}

Spectral irradiance vs wavelength incident to perpendicular, horizontal and into module plane, $\mathrm{W} / \mathrm{m}^{2} / \mathrm{nm}$ : see Figure 12

Power density (perpendicular and into module location) $\left(\mathrm{W} / \mathrm{m}^{2}\right)$ : see Figure 16 Photon current (perpendicular and into module location) $\left(\mathrm{mA} / \mathrm{cm}^{2}\right)$ : see Figure 17

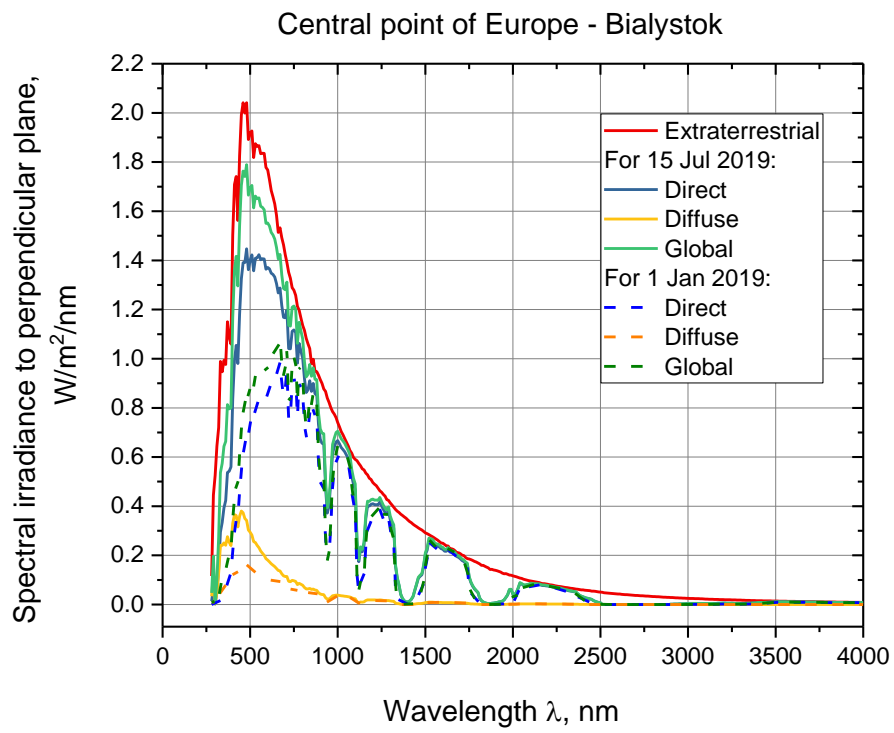

Figure 8. Spectral irradiance vs wavelength incident on the perpendicular plane (Białystok)

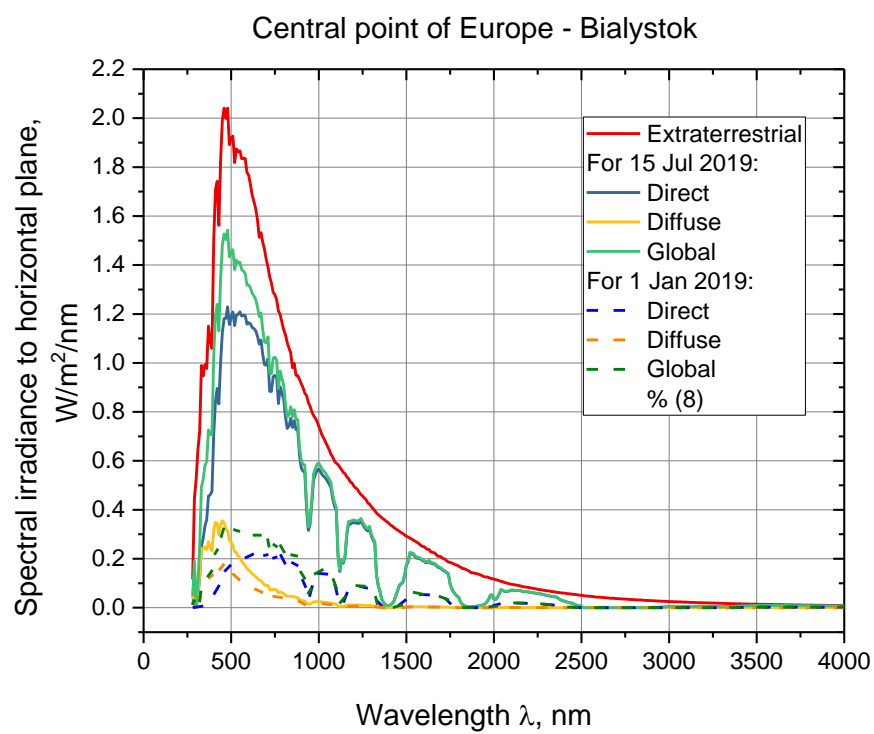

Figure 9. Spectral irradiance vs wavelength incident on the horizontal plane (Białystok) 


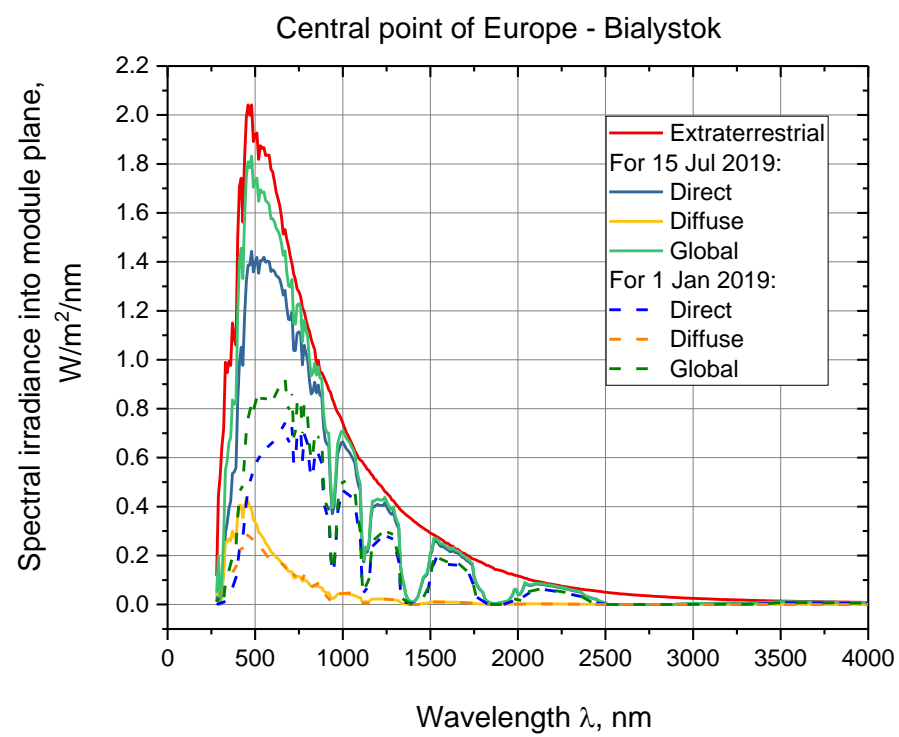

Figure 10. Spectral irradiance vs wavelength incident on the module plane (Białystok) for 15 July

In addition, for the geometric centre of Europe - Białystok, Figure. 11 presents sample atmospheric transmission vs wavelength, taking into account variables implemented into a computational algorithm, which include: Rayleigh scattering, aerosol scattering, water vapour absorption, ozone absorption and unmixed gas absorption.

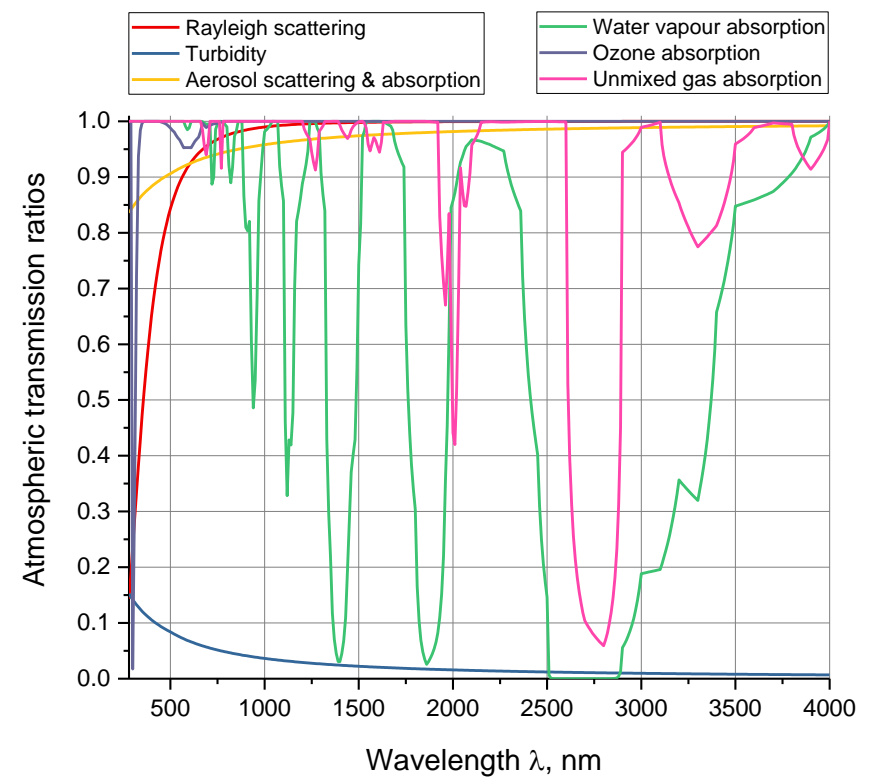

Figure 11. Atmospheric transmission vs wavelength 


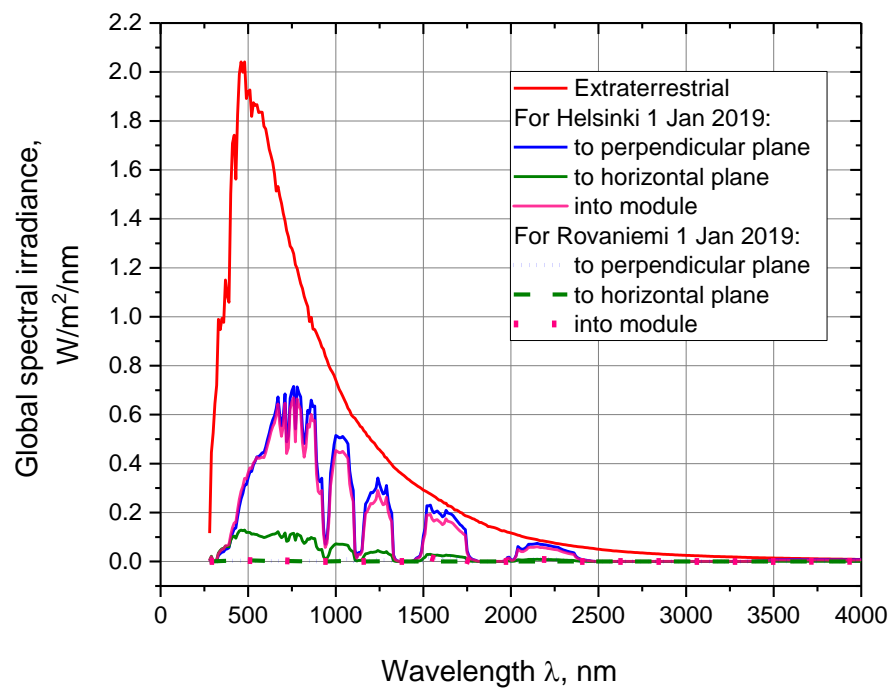

Figure 12. Comparison of spectral data for northern and southern Finland as of 1 January 2019

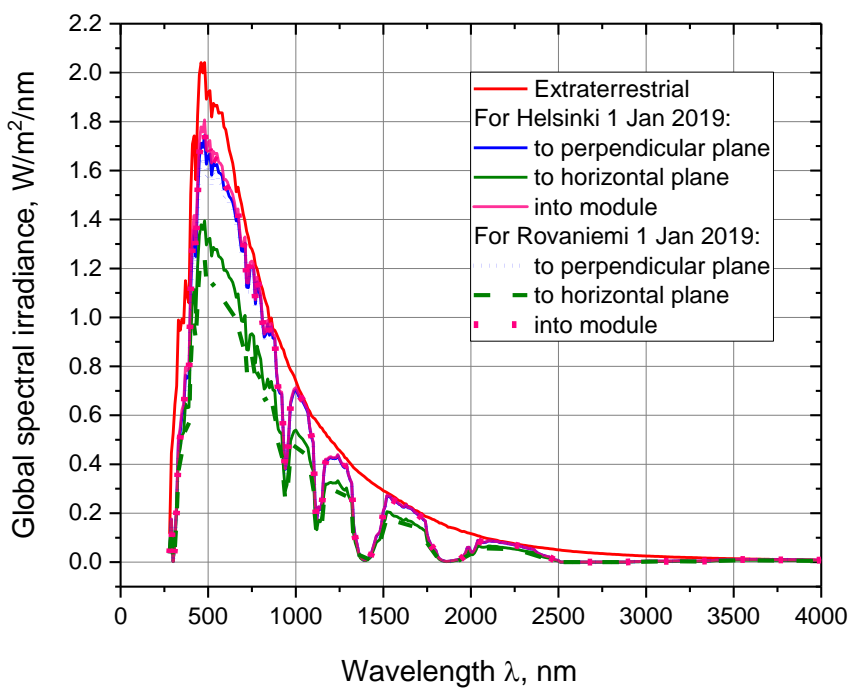

Figure 13. Comparison of spectral data for northern and southern Finland as of 15 July 2019

Graphs 14 and 15 present differences between direct, diffuse and global power density and photon current in the central point of Europe in comparison to the results from Malta (Valletta) and Finland (Helsinki) for perpendicular and into module solar irradiation; the values are related to simulations of insolation as of 15 July 2019. 


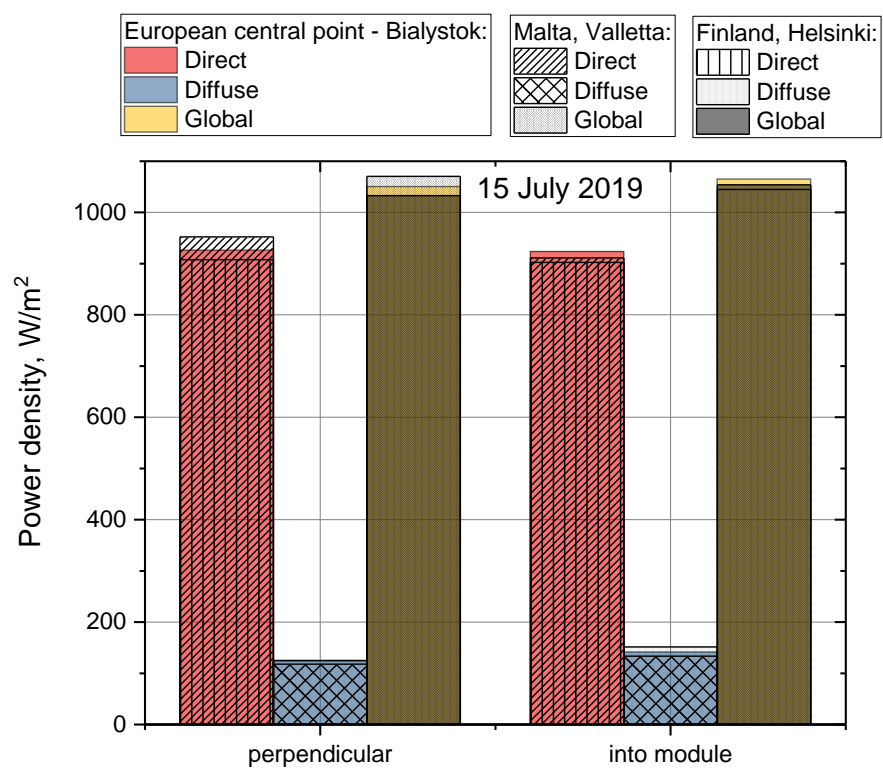

Figure 14. Direct, diffuse and global power density in the central point of Europe in comparison to Maltese and Finnish results for perpendicular and into module solar irradiation (integrated over a wavelength range of 280-4000 nm); 15 July 2019.

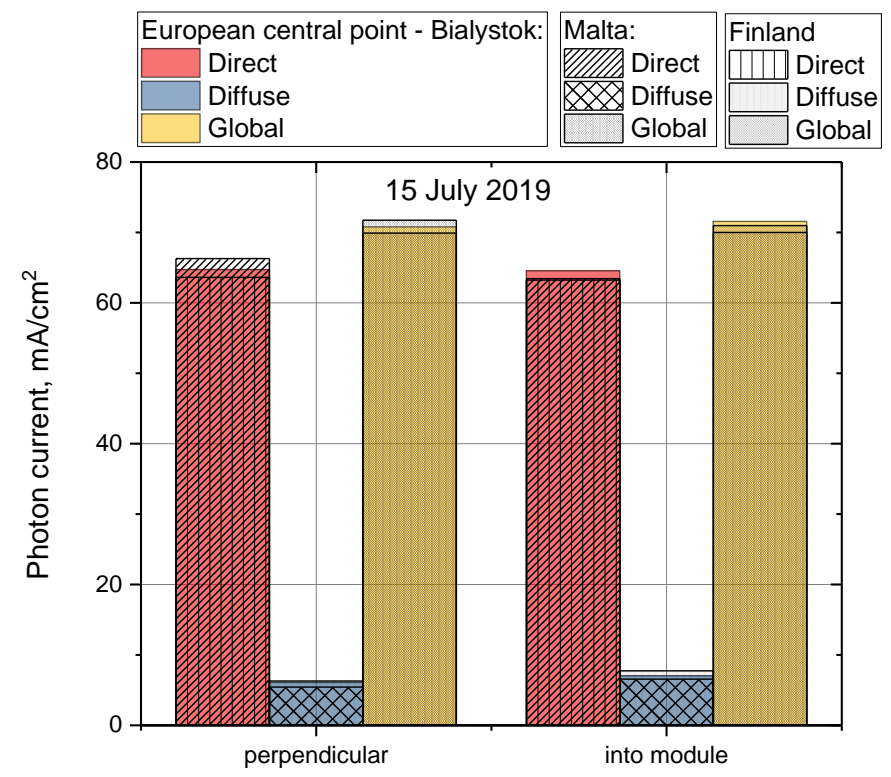

Figure 15. Direct, diffuse and global photon current in the central point of Europe in comparison to Maltese results for perpendicular and into module solar irradiation (integrated over a wavelength range of 280-4000 nm); 15 July 2019.

As can be seen based on Figures 14 and 15, the middle of summer, which is considered to occur on the 15th of July, does not exhibit high variances in insolation in each one of the analysed cases. The difference between the values of power density and photon current for Poland, Malta and Finland does not exceed $3.5 \%$ both for solar rays with perpendicular incidence and those with an average optimal angle for a given country, amounting to 36, 32 and 45, respectively.

However, considering the data on insolation for January, in which the average respective numbers of sunshine hours recorded for Poland and Malta amount to 31 [34] and 169 [35] (meaning 5.5 times more solar energy in Malta in January and 33\% more annually), the modelled values of power density and photon current exhibit considerable variability. Therefore, between the central point of Europe - Białystok (Poland), the capitals of Malta - Valletta and Finland - Helsinki, the respective differences in power density amount to 37 and 36\% for direct, 37 and 50\% for scattered, 41 
and $37 \%$ for total solar irradiation directed perpendicular to the plane, as well as 60 and $34 \%$ for direct, 26 and $27 \%$ for scattered, 54 and 33\% for total solar irradiation directed at an average optimal angle for a given location (see Figure 16).

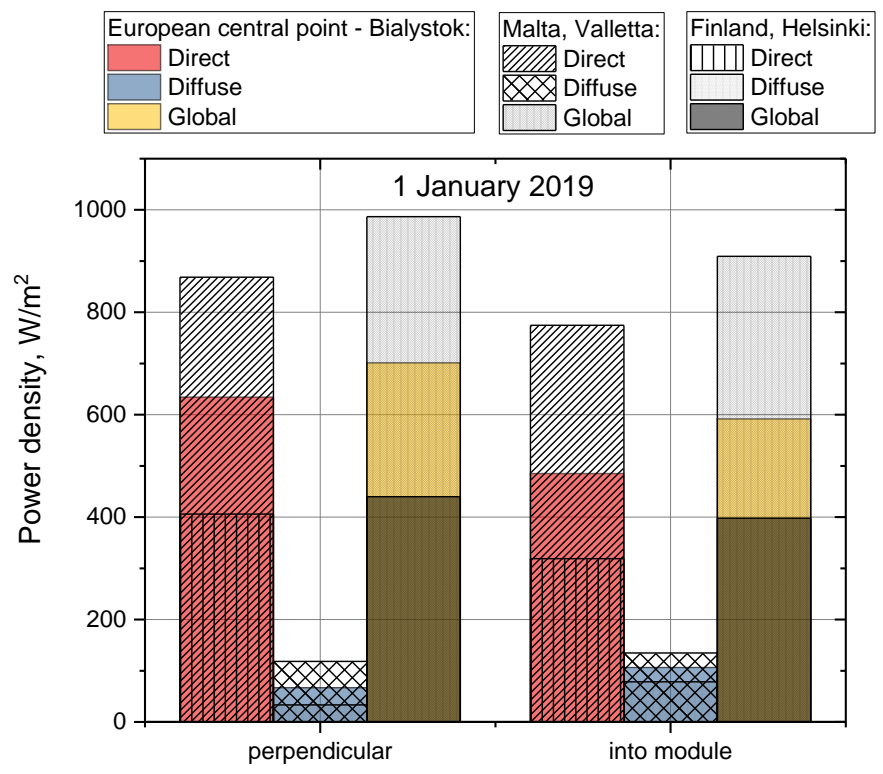

Figure 16. Direct, diffuse and global power density in the central point of Europe in comparison to Maltese and Finnish results for perpendicular and into module solar irradiation (integrated over a wavelength range of 280-4000 nm); 1 January 2019.

As regards the estimated difference between the potential utilisation of electrical energy from solar photons, the relationships are comparable. Thus, the photon current amounts to 29 and $30 \%$ for direct, 69 and $49 \%$ for scattered, 32 and 31\% for total solar irradiation directed perpendicular to the plane, as well as 50 and $28 \%$ for direct, 18 and $17 \%$ for scattered, 46 and $27 \%$ for total solar irradiation directed at an average optimal angle for a given location, respectively (see Fig. 17).

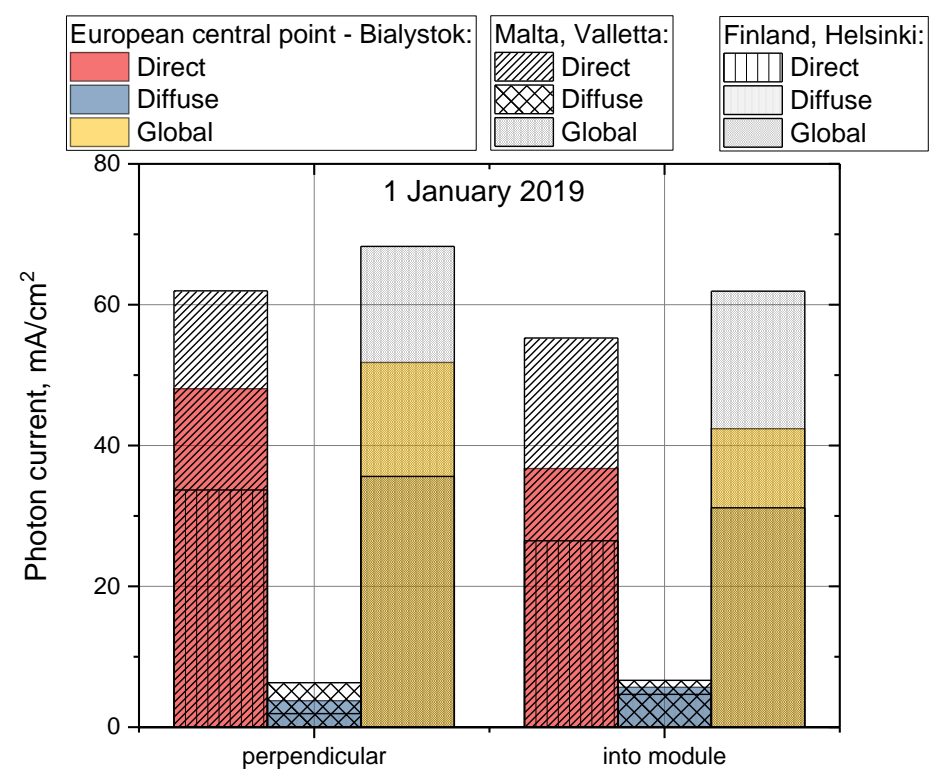

Figure 17. Direct, diffuse and global photon current in the central point of Europe in comparison to Maltese and Finnish results for perpendicular and into module solar irradiation (integrated over a wavelength range of 280-4000 nm); 1 January 2019 
However, when the above values are related to the city of Rovaniemi (Finland), located in the Arctic Circle, the respective estimated differences in power density and the energy of photons will each time amount to approx. 98 and 97\% (see Figures. 18 and 19).

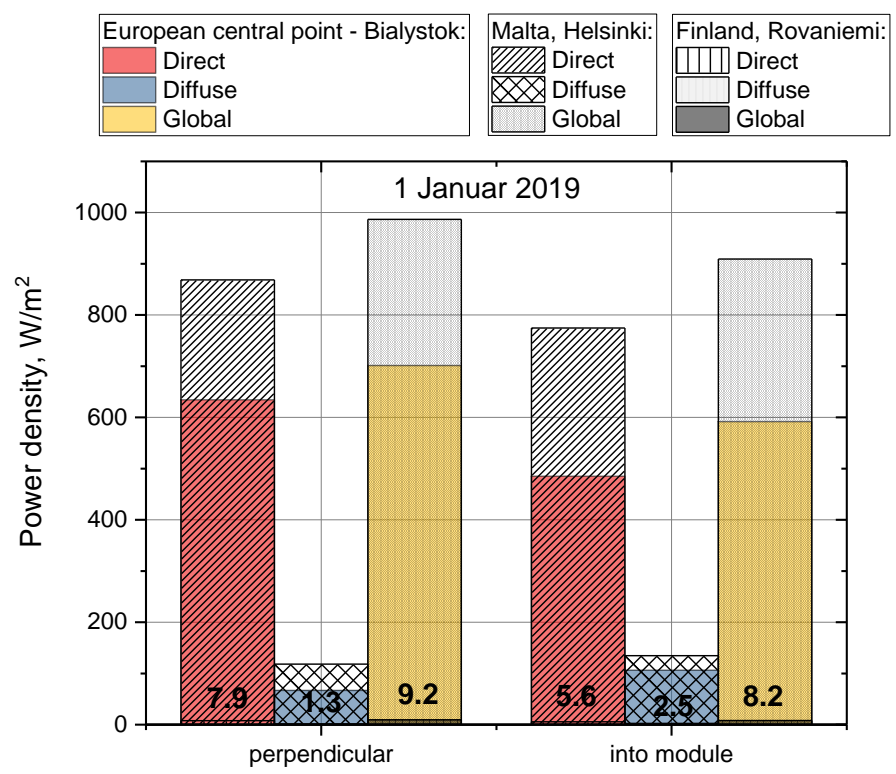

Figure 18. Direct, diffuse and global power density in the central point of Europe in comparison to Maltese and Finnish (Rovaniemi) results for perpendicular and into module solar irradiation (integrated over a wavelength range of $280-4000 \mathrm{~nm}$ ).

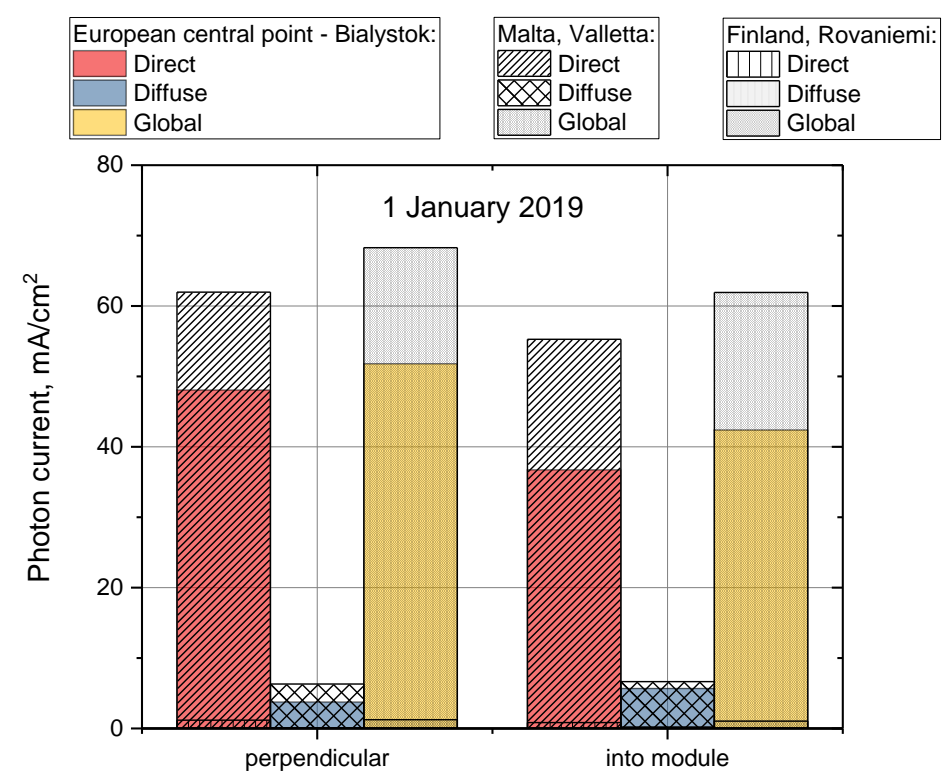

Figure 19. Direct, diffuse and global photon current in the central point of Europe in comparison to Maltese and Finnish (Rovaniemi) results for perpendicular and into module solar irradiation (integrated over a wavelength range of $280-4000 \mathrm{~nm})$.

The PV Lighthouse environment also enables determining the path of the Sun as it traverses the sky. It can be used to calculate the average number of sunlight hours in a day or year for any location. Graph 20 was prepared on this basis, clearly showing the high diversity in the number of sunlight hours in the analysed countries of Europe. 


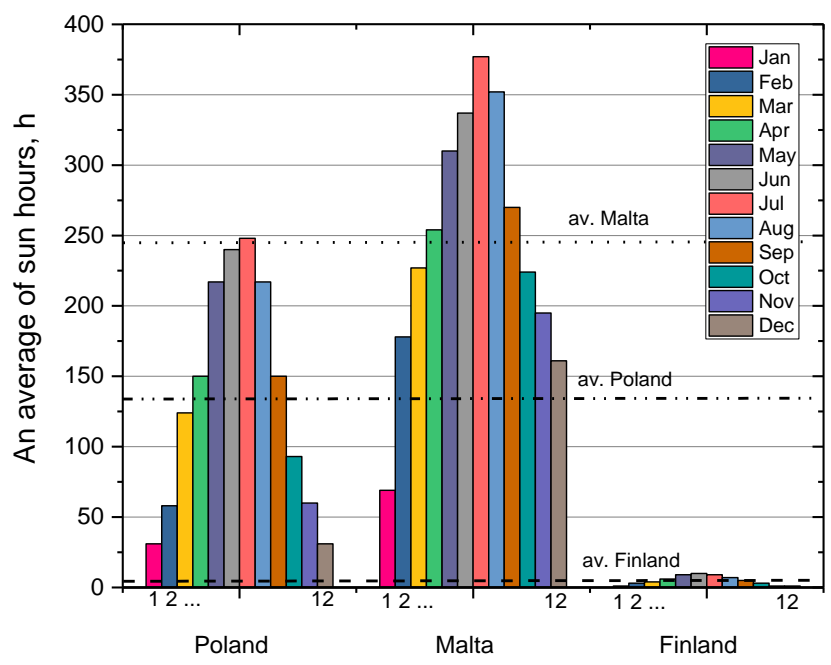

Figure 20. The average number of sun hours for Poland, Malta and Finland.

In addition, the graphs (Figure 21 - 24) of solar path and sunlight during the year in the analysed locations are presented as a supplement of the analysis performed above.
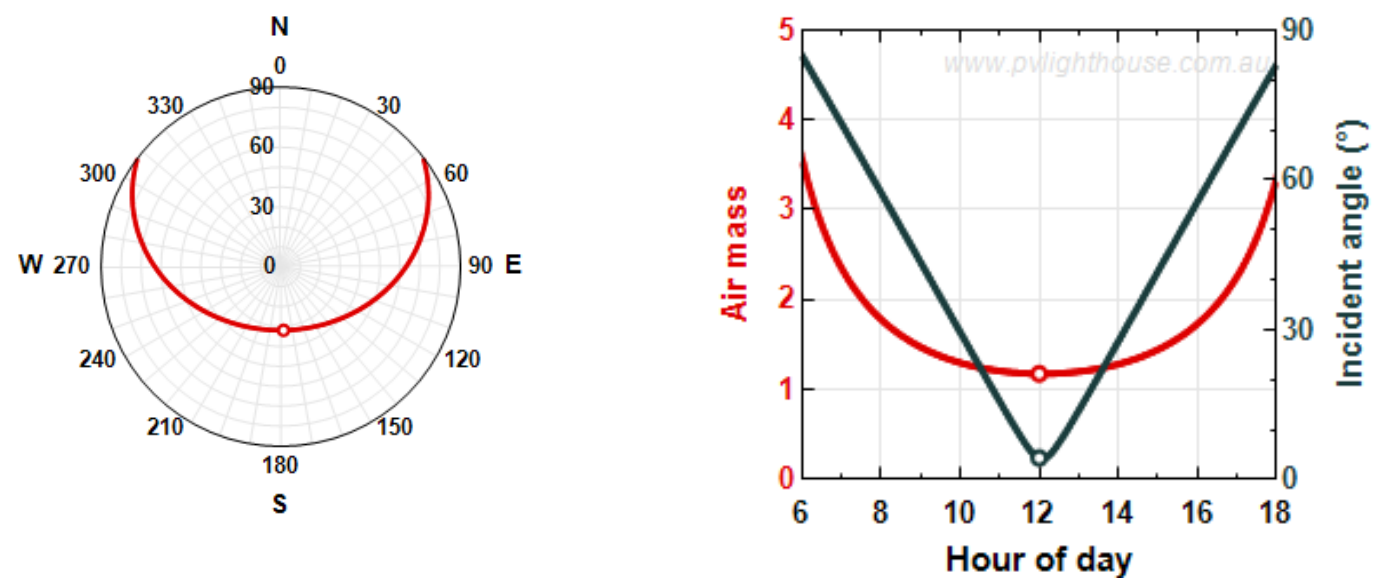

(a)

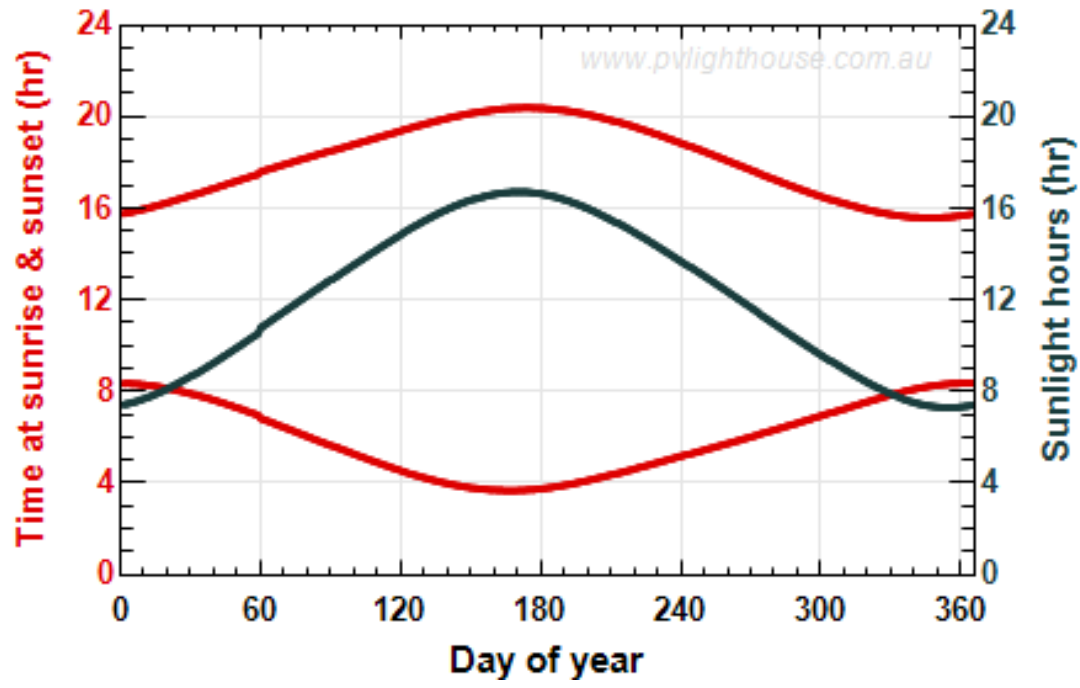

(b) 
Figure 21. (a) Solar path on 15-July-2019 and (b) sunlight during the year for the Białystok location - the geometrical centre of Europe
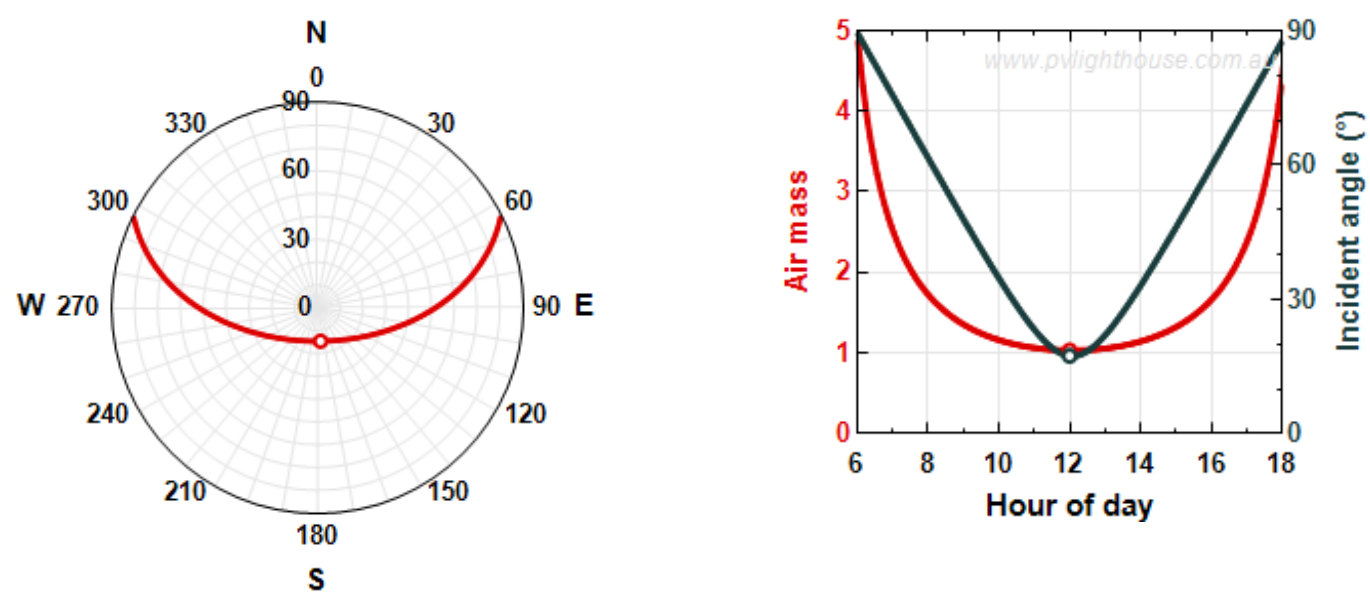

(a)

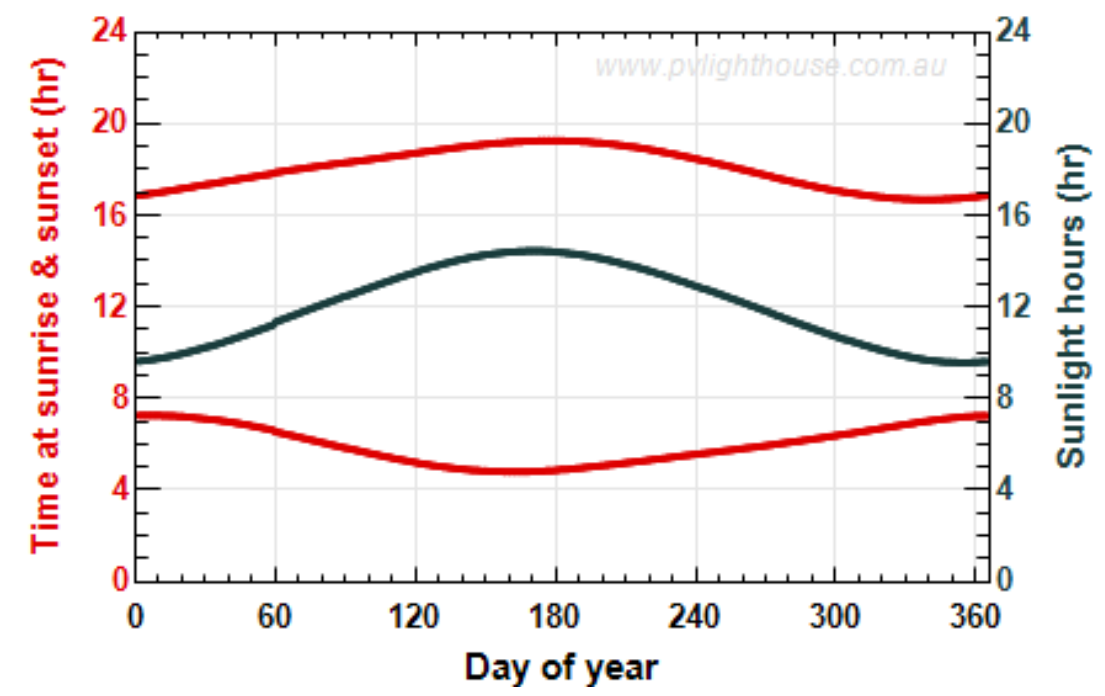

(b)

Figure 22. (a) Solar path on 15-July-2019 and (b) sunlight during the year for the Valetta location
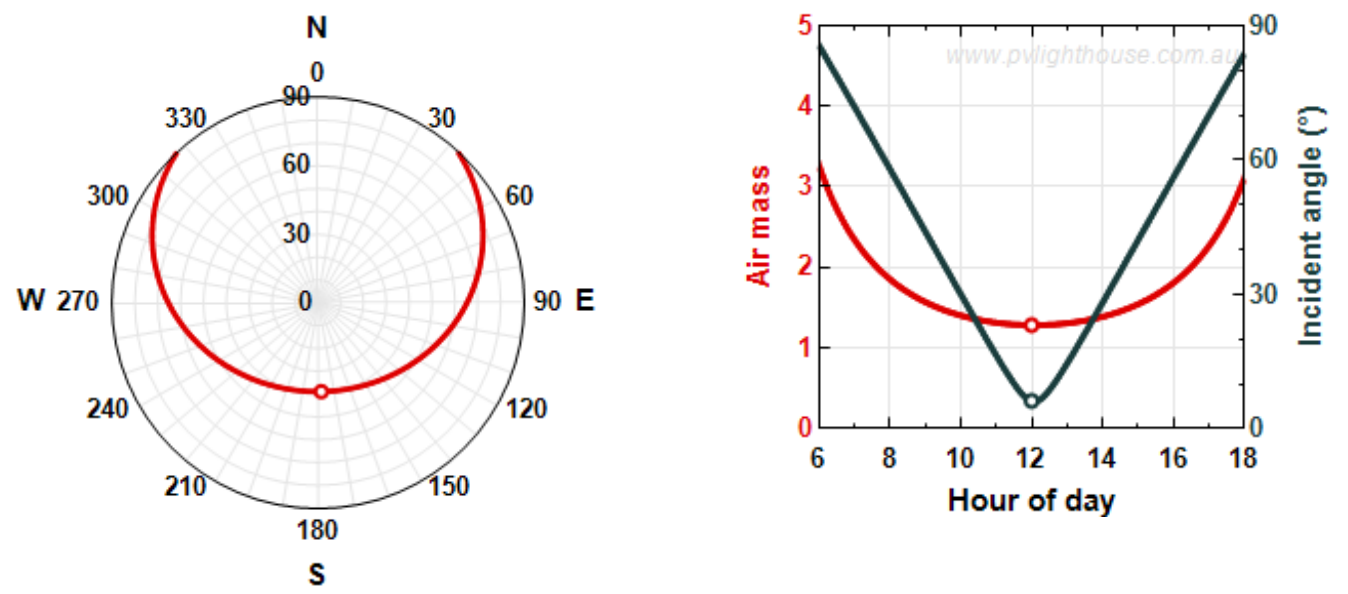

(a) 


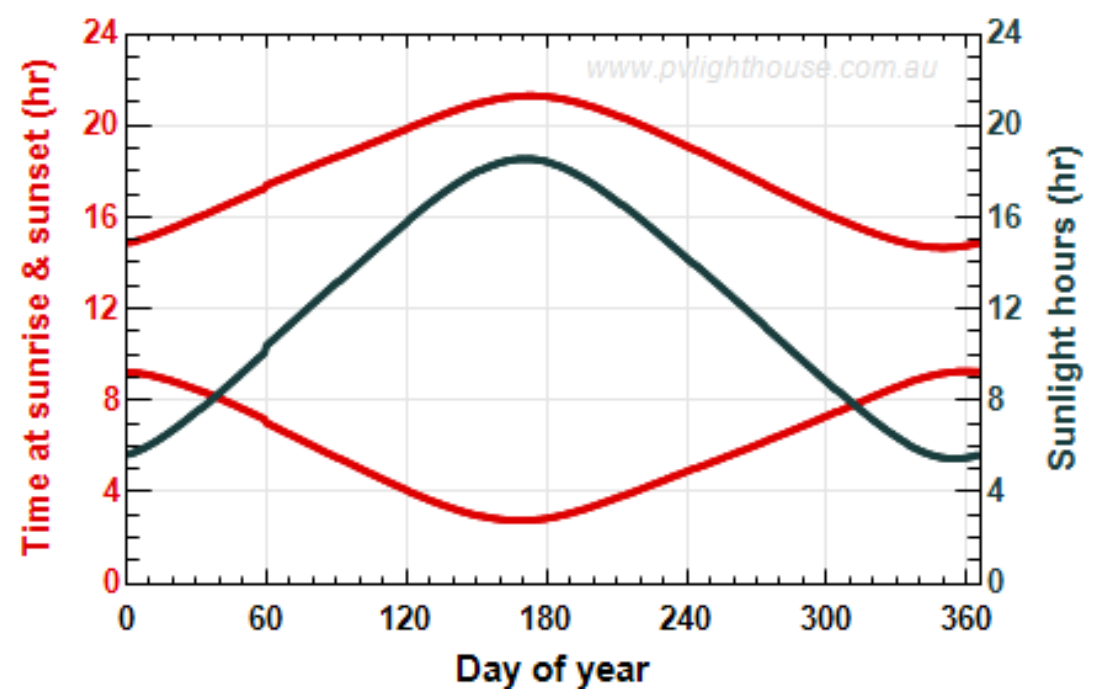

(b)

Figure 23. (a) Solar path on 15-July-2019 and (b) sunlight during the year for the Helsinki location
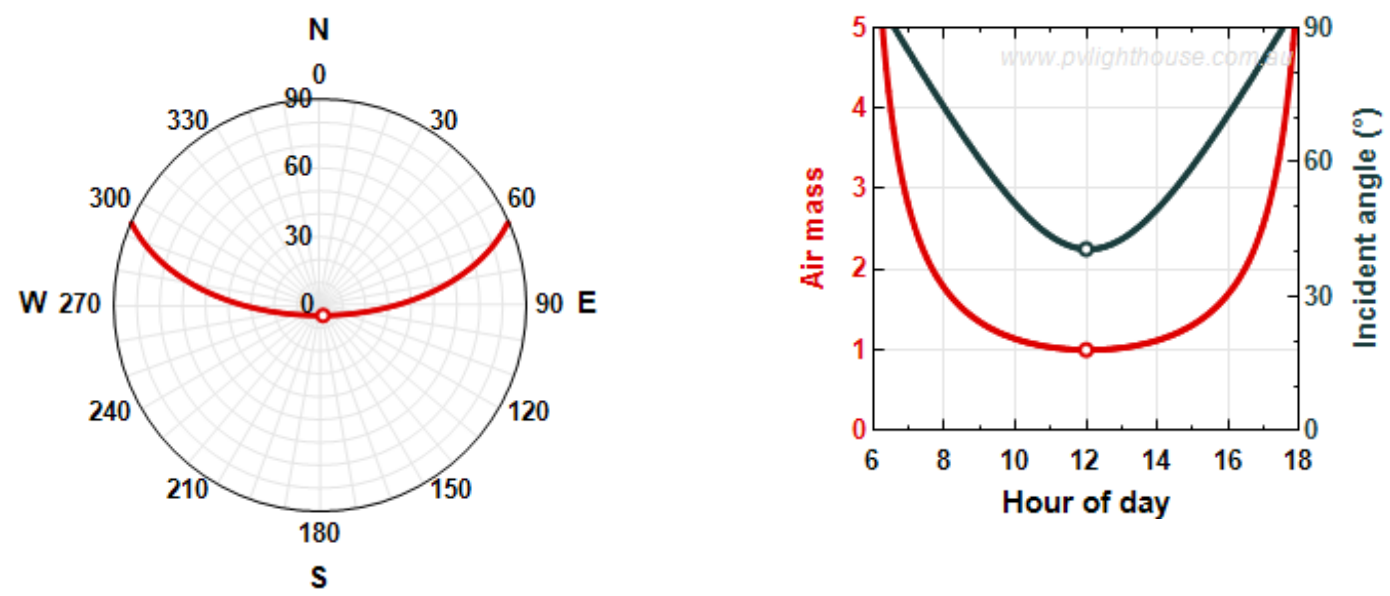

a)

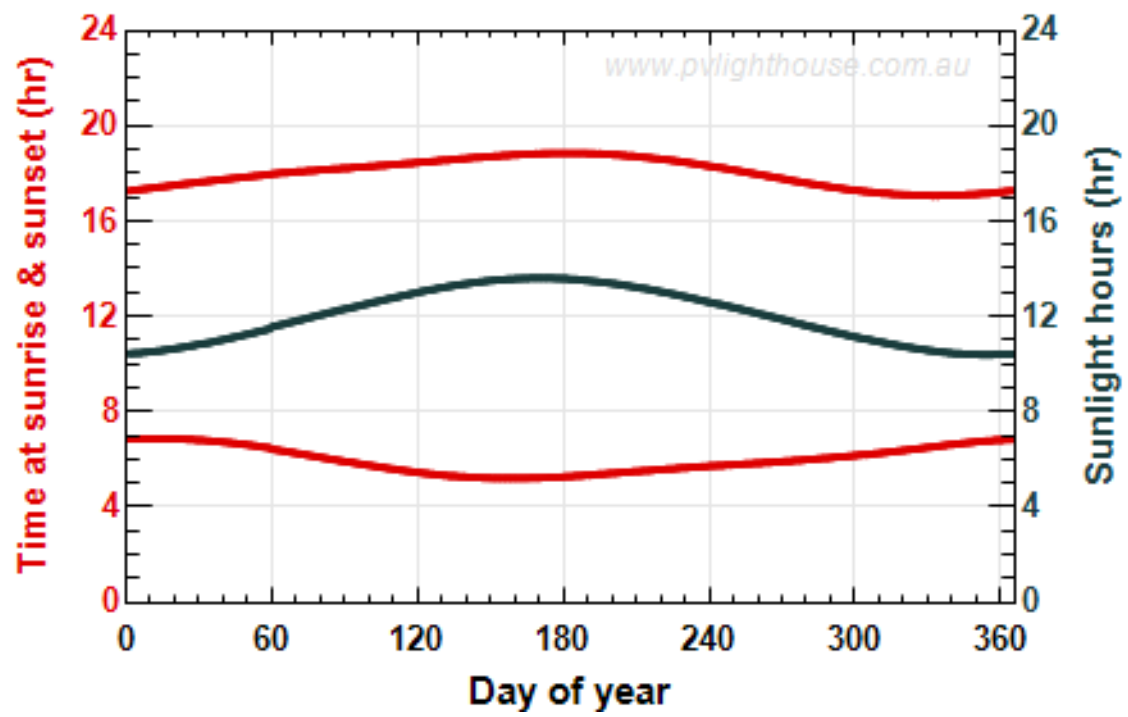

(b)

Figure 24. (a) Solar path on 15-July-2019 and (b) sunlight during the year for the Rovaniemi location

The presented optimization could be also conducted using SMARTS software. It seems to be a slightly more complicated and complex tool, being used by scientists and engineers to test the 
capacity of devices such as spectroradiometers or spectrophotometers, and to verify broadband irradiance beam models, determine the reference spectra (e.g. ASTM G-173 and ASTM G-177) used by the American Society of Testing and Materials (ASTM), the deterioration of materials (e.g. in photovoltaics) subjected to long solar exposure; the software calculates, for a specific wavelength, the impact of the changing composition of Earth's atmosphere on the distribution of solar irradiation energy or photon energy.

The program is written in the FORTRAN language; an implemented algorithm enables presenting the relationship between atmospheric attenuation, as a function of changing albedo, and optical depth. The proposed spectral resolution varies depending on irradiation wavelength, and thus for a UV range of $280-400 \mathrm{~nm}$ it amounts to $0.5 \mathrm{~nm}$, for a $400-1750 \mathrm{~nm}$ range it is $1 \mathrm{~nm}$, and for $1750-4000 \mathrm{~nm}$ it amounts to $10 \mathrm{~nm}$. However, on our part, we believe that the software is highly unstable and it often displays errors or crashes without any reason.

\section{Optimisation of the Size of a PV Installation Cooperating with a Heat Pump}

In order to determine the size and estimated costs of a photovoltaic installation (supporting the operation of a heat pump), as well as static and dynamic pay-back time indicators for investment expenses, necessary auditing calculations were performed for a sample educational building (with an area with adjusted temperature of $\mathrm{A}_{\mathrm{f}}=1324.29 \mathrm{~m}^{2}$ ) located in Białystok - near the geometrical centre of Europe.

Table 2 presents basic and necessary input data for further analysis. In the current ' 0 ' status, the building is heated by means of a boiler fired with type E methane-rich natural gas; an electric brinewater heat pump supported by a PV installation has been proposed for use after thermal upgrading. Upon thermal upgrading, also encompassing the enhancement of heat insulation, the design heat load and usable energy decreased by $30 \%$. Calculations of the annual amounts of carbon dioxide emitted into the atmosphere and its ecological effect are based on emission indicators listed in table 3 [36].

Table 2. A list of input data for determining the size of a PV installation

\begin{tabular}{|c|c|c|}
\hline Option & $` 0^{\prime}$ & $' 1 '$ \\
\hline Fuel type & Natural gas, type E & Heat pump + PV cells \\
\hline Boiler station power, $\mathrm{kW}$ & 300 & 210 \\
\hline $\begin{array}{l}\text { Usable energy for central heating and } \\
\text { domestic hot water, GJ/year }\end{array}$ & 1531 & 1072 \\
\hline Cost of 1 GJ, EUR/GJ & 14.86 & $0.92^{2}$ \\
\hline Estimated yearly fuel consumption & $\begin{array}{l}V_{E}=51037 \\
\mathrm{~m}^{3} / \text { annum }^{1}\end{array}$ & $\begin{array}{l}P_{e l_{P C}}=82704 \\
\mathrm{kWh} / \text { annum }\end{array}$ \\
\hline $\begin{array}{l}\text { Estimated annual consumption of } \\
\text { electricity by the boiler assembly, } P_{A K} \text {, } \\
\mathrm{kWh} / \text { year }\end{array}$ & 4320 & 3025 \\
\hline Estimated length of the heating period & \multicolumn{2}{|l|}{200 days } \\
\hline
\end{tabular}

${ }^{1}$ ) according to the investor's information; ${ }^{2}$ )operating cost of the heat pump, assuming that $90 \%$ of electrical energy originates from the PV installation: $9.20 \mathrm{EUR} / \mathrm{GJ} \times 10 \%=0.92 \mathrm{EUR} / \mathrm{GJ}$

Table 3. Calorific values (WO) and $\mathrm{CO}_{2}$ emission indicators (WE) in 2017 for reporting under the emissions trading system for 2020

\begin{tabular}{|l|l|l|}
\hline Fuel type & WO & $\mathrm{WE} \mathrm{CO}_{2}$ \\
\hline Electrical energy & $3.6 \mathrm{MJ} / \mathrm{kWh}$ & $93.63 \mathrm{~kg} / \mathrm{GJ}$ \\
\hline
\end{tabular}




\begin{tabular}{|l|l|l|}
\hline Methane-rich natural gas, type E & $36.54 \mathrm{MJ} / \mathrm{m}^{3}$ & $55.41 \mathrm{~kg} / \mathrm{GJ}$ \\
\hline
\end{tabular}

In order to establish the direct ecological effect of the investment [37], the first step involves determining the emission of $\mathrm{CO}_{2}$ from a natural gas boiler station, for option '0' (formulas 1-3), the next one focusing on a boiler station based on a system of heat pumps (formulas 4-5); the combined results and the achieved reduction in $\mathrm{CO}_{2}$ are presented in tables 4 and 5.

Annual emission of $\mathrm{CO}_{2}$ from a natural gas boiler:

$$
E_{E}^{\mathrm{CO}_{2}}=V_{E} \cdot W O_{E} \cdot W E_{E}
$$

Annual emission of $\mathrm{CO}_{2}$ from electrical energy for powering the boiler assembly:

$$
E_{e l_{A K}}^{\mathrm{CO}_{2}}=P_{e l_{A K}} \cdot W O_{e l} \cdot W E_{e l}
$$

Total annual emission of $\mathrm{CO}_{2}$ for the boiler station:

$$
E_{E_{t o t}}^{\mathrm{CO}_{2}}=E_{E}^{\mathrm{CO}_{2}}+E_{e l_{A K}}^{\mathrm{CO}_{2}}
$$

Annual emission of $\mathrm{CO}_{2}$ from electrical energy for powering the heat pumps:

$$
E_{e l_{P C}}^{\mathrm{CO}_{2}}=E_{e l_{P C}}=P_{e l_{P C}} \cdot W O_{e l} \cdot W E_{e l}
$$

Combined annual emission of $\mathrm{CO}_{2}$ for a system based on heat pumps:

$$
\begin{gathered}
E_{e l_{t o t}}^{\mathrm{CO}_{2}}=E_{e l_{P C}}^{\mathrm{CO}_{2}}+E_{e l_{A K}}^{\mathrm{CO}_{2}} \\
E_{e l_{P C}}^{\mathrm{CO}_{2}}=82,704 \mathrm{kWh} \cdot 3.6 \frac{\mathrm{MJ}}{\mathrm{kWh}} \cdot 93.63 \frac{\mathrm{kg}}{\mathrm{GJ}}=27,876.87 \frac{\mathrm{kg}}{\text { year }} \\
E_{e l_{A K}}^{\mathrm{CO}_{2}}=3,025 \mathrm{kWh} \cdot 3.6 \frac{\mathrm{MJ}}{\mathrm{kWh}} \cdot 93.63 \frac{\mathrm{kg}}{\mathrm{GJ}}=1,019.63 \frac{\mathrm{kg}}{\text { year }} \\
E_{e l_{\text {tot }}}^{\mathrm{CO}_{2}}=27,876.87+1,019.63=28,896.5 \frac{\mathrm{kg}}{\text { year }}
\end{gathered}
$$

Resulting reduction in $\mathrm{CO}_{2}$ for a system based on heat pumps:

$$
E_{\text {red. }}=1-\frac{E_{\text {eltot }}^{C O_{2}}}{E_{E_{\text {tot }}}^{C O_{2}}} \cdot 100, \%
$$

Table 4. Results of the calculations of $\mathrm{CO}_{2}$ emissions for the current status and with alternative energy sources

\begin{tabular}{|c|l|c|}
\hline \multirow{2}{*}{$\mathrm{CO}_{2}$ emission } & \multicolumn{2}{|l|}{ Option } \\
\cline { 2 - 3 } & $‘ 0{ }^{\prime}$ & ' $1{ }^{\prime}$ \\
\hline $\mathrm{kg} / \mathrm{rok}$ & & \\
\hline$E_{E, P C}^{C O_{2}}$ & 103333.66 & 27876.87 \\
\hline$E_{\text {el }}^{C l_{A K}}$ & 1456.13 & 1019.63 \\
\hline$E_{\text {tot }}^{C O_{2}}$ & 104789.79 & 28896.5 \\
\hline$E_{\text {red. }}, \%$ & \multicolumn{2}{|c|}{72.42} \\
\hline
\end{tabular}

Table 5. Direct ecological effect of the investment*)

\begin{tabular}{|l|c|c|c|c|}
\hline $\begin{array}{c}\text { Emitted } \\
\text { pollution }{ }^{1)}\end{array}$ & $\begin{array}{c}\text { Option } \\
\text { '0' }\end{array}$ & $\begin{array}{c}\text { Option } \\
'{ }^{\prime}\end{array}$ & $\begin{array}{c}\text { Ecological } \\
\text { effect }\end{array}$ & $\begin{array}{c}\text { Emission } \\
\text { reduction }\end{array}$ \\
\hline & \multicolumn{3}{|c|}{$\mathrm{kg} / \mathrm{rok}$} & $\%$ \\
\hline $\mathrm{SO}_{2}$ & 39.31 & 78.01 & -38.70 & -98.46 \\
\hline $\mathrm{NOx}$ & 75.26 & 19.72 & 55.54 & 73.80 \\
\hline $\mathrm{CO}$ & 21.35 & 5.92 & 15.44 & 72.30 \\
\hline $\mathrm{CO}_{2}$ & 104556.32 & 8572.90 & 95983.42 & $\mathbf{9 1 . 8 0}$ \\
\hline $\mathrm{PY}$ & 7.25 & 12.86 & -5.61 & -77.49 \\
\hline
\end{tabular}




\begin{tabular}{|l|c|c|c|c|}
\hline SADZA & 0.01 & 0.02 & -0.01 & -98.46 \\
\hline B-a-P & 0.00 & 0.00 & 0.00 & -98.46 \\
\hline
\end{tabular}

1) except for $\mathrm{CO}_{2}$, the ratios of unit emissions are specified based on [36]; negative values represent an increase in emissions, with positive ones for reduction

The next step involved determining the required minimum power of PV cells amounting to $P_{m i n}=$ $36.43 \mathrm{~kW}$ (relationship (7)) and their number $n_{P V}=182$, in order to achieve a minimum reduction in $\mathrm{CO}_{2}$ emission of $90 \%$ relative to the current status.

$$
\begin{aligned}
& P_{\min }=\frac{E_{\text {el }}^{C O_{2}}-\left(E_{E_{t o t}}^{C O_{2}} \cdot 10 \%\right) \cdot 1000}{W O_{e l} \cdot W E_{e l}}, \frac{k W h}{\text { year }} \\
& P_{\text {min }}=\frac{28896.5-(104789.79 \cdot 10 \%) \cdot 1000}{3.6 \cdot 93.63}=54640.37 \frac{k W h}{y e a r}=\frac{54640.37}{200 d}=273.20 \frac{k W h}{d} \\
& =\frac{273.20}{7.5 h}=36.43 \mathrm{~kW}
\end{aligned}
$$

The required number of PV panels:

$n_{P V}=\frac{36.43}{0.2} \cong 182$ pcs

In order to select the minimum number of PV cells, it was assumed that the estimated average daily time of harvesting energy by photovoltaic cells for the winter period is $7.5 \mathrm{~h}$, the surface area of a single photovoltaic panel $-1.6 \mathrm{~m}^{2}$, and the recovery of electrical power from a single panel is $0.2 \mathrm{~kW}$.

\subsection{Power production estimation for grid-connected, tracking and off-grid systems.}

The simulation performed using the Photovoltaic Geographical Information System (PVGIS) application [38] allowed comparing the production of energy in a photovoltaic system PV for three cases:

1. on-grid,

2. in a tracking system,

3. off-grid

The calculations were performed for the same locations which are analysed above: Białystok the geometrical centre of Europe, the capital of Malta - Valletta, and the city of Rovaniemi situated in the Arctic Circle, in Finland. The results of the simulation are presented on graphs 25-27 and exemplary simulation inputs and outputs are provided below:

\begin{tabular}{|c|c|c|c|}
\hline & OFF-grid & ON-grid & TRACKING \\
\hline \multicolumn{4}{|c|}{ Simulation inputs: } \\
\hline Database used: & \multicolumn{3}{|c|}{ PVGIS-SARAH } \\
\hline PV installed & \multicolumn{3}{|l|}{$58240 \mathrm{Wp}$} \\
\hline Cutoff limit & $40 \%$ & - & - \\
\hline System loss & & \multicolumn{2}{|l|}{$14 \%$} \\
\hline Battery capacity & $378720 \mathrm{Wh}$ & - & - \\
\hline
\end{tabular}

Table 6. An exemplary simulation inputs and outputs for the Bialystok location - the geometrical centre of Europe 


\begin{tabular}{|c|c|c|c|}
\hline Consumption per day & $273000 \mathrm{Wh}$ & & \\
\hline Slope angle & \multicolumn{2}{|l|}{$38^{\circ}$} & \\
\hline Azimuth angle & $-2^{\circ}$ & & \\
\hline \multicolumn{4}{|l|}{ Simulation outputs: } \\
\hline Percentage days with full battery & $5.5 \%$ & - & - \\
\hline Percentage days with empty battery & $88.46 \%$ & - & - \\
\hline Average energy not captured & $29370.02 \mathrm{Wh}$ & - & - \\
\hline Average energy missing & $161346.07 \mathrm{Wh}$ & - & - \\
\hline Yearly PV energy production: & & $57019.89 \mathrm{kWh}$ & 75146.05 \\
\hline Yearly in-plane irradiation & & $1215.94 \mathrm{kWh} / \mathrm{m}^{2}$ & 1581.47 \\
\hline Year-to-year variability: & & $3042.82 \mathrm{kWh}$ & 3980.4 \\
\hline \multicolumn{4}{|l|}{ Changes in output due to } \\
\hline Angle of incidence: & & $-3 \%$ & -1.72 \\
\hline Spectral effects & & $1.7 \%$ & 1.67 \\
\hline Temperature and low irradiance & & $-5.09 \%$ & -5.06 \\
\hline Total loss: & & $-19.48 \%$ & -18.41 \\
\hline
\end{tabular}

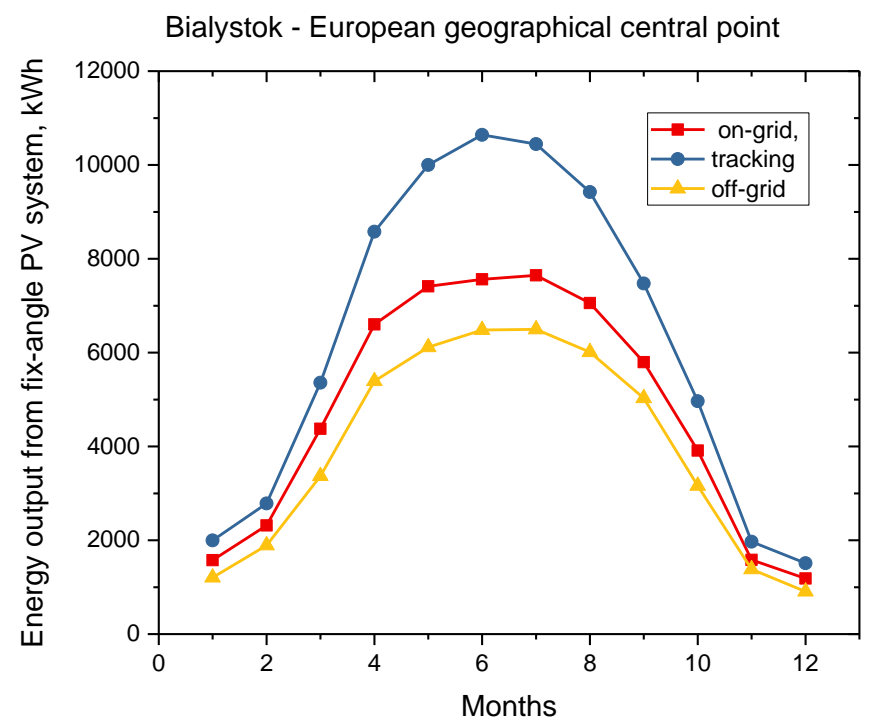

Figure 25. The amount of electrical energy generated in a photovoltaic system for the Białystok location - the geometrical centre of Europe 


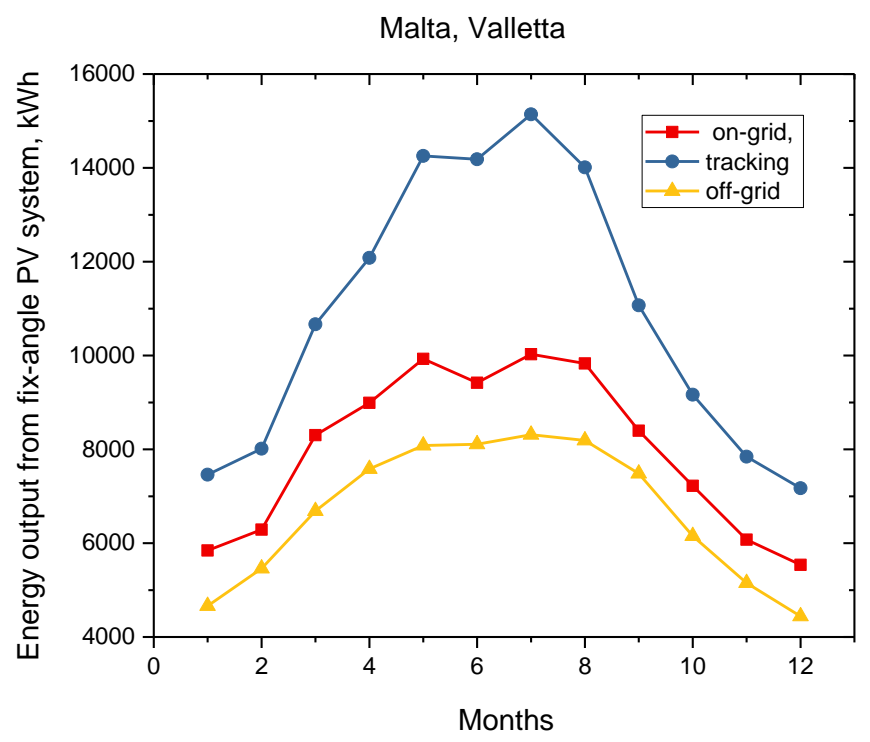

Figure 26. The amount of electrical energy generated in a photovoltaic system for the Malta, Valletta location

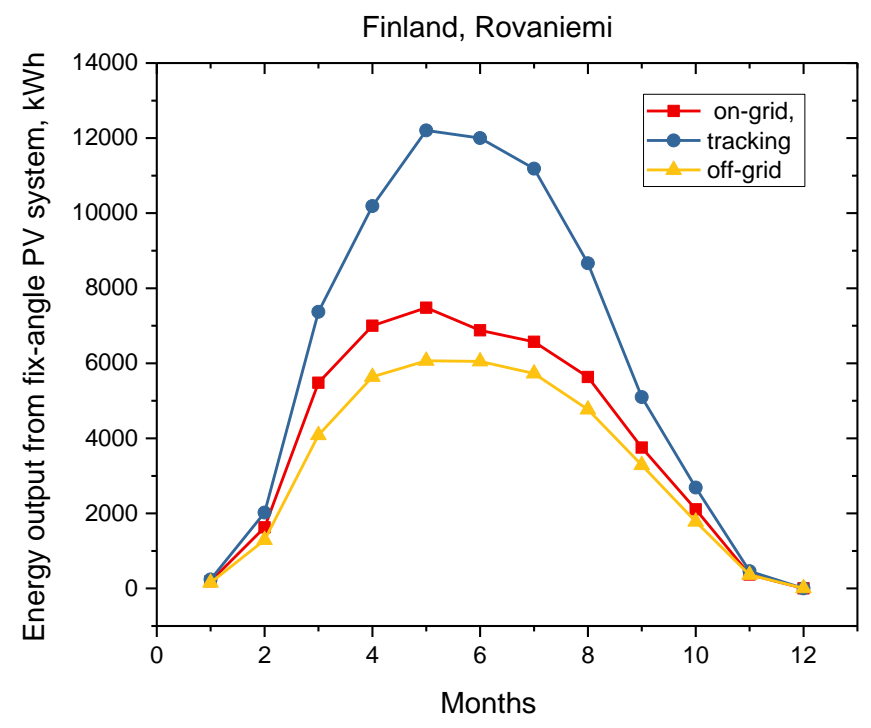

Figure 27. The amount of electrical energy generated in a photovoltaic system for the Finland, Rovaniemi location

\subsection{Simple and discounted indicators of economic efficiency}

For the options of thermal upgrading analysed in an energy audit (improvement groups), at least the following simple and discounted indicators of economic efficiency are calculated:

- $\quad$ SPBT (Simple Pay-Back Time) - static method,

- NPV (Net Present Value) - dynamic method,

- IRR (Internal Rate of Return) - dynamic method

In the analysed case, the Simple Pay-Back Time SPBT of expenses paid for an investment related to deep thermal upgrading, including primarily an exchange of the heat source $\left(\mathrm{N}_{1}=201913 \mathrm{EUR}\right)$, the purchase and assembly of photovoltaic panels $\left(\mathrm{N}_{2}=121859\right.$ EUR) and gel batteries $\left(\mathrm{N}_{3}=154525\right.$ EUR) amounts to almost 22 years, which in the practice of investment economics is considered as an 
infeasible undertaking. Assumptions presented in Table 7 were made in order to estimate the static indicator of profitability, which is the SPBT.

Table. 7. Assessment of the feasibility of modernisation of a heating installation

\begin{tabular}{|l|c|c|}
\hline \multirow{2}{*}{ Feasibility assessment parameters } & \multicolumn{2}{|c|}{ Option } \\
\cline { 2 - 3 } & ${ }^{\prime} 0^{\prime}$ & $'{ }^{\prime}$ \\
\hline Fare for 1 GJ of heating, EUR/GJ & 14.86 & 0.92 \\
\hline Heating system efficiency & 0.662 & 3.202 \\
\hline Yearly cost savings $\odot \mathrm{O}$, EUR/a & --- & 21768.65 \\
\hline Cost of modernisation - expenses, ๑N, EUR & --- & 478298 \\
\hline SPBT $=\mathrm{N} / \sim \mathrm{O}$, year & & 21.97 \\
\hline
\end{tabular}

Moreover, assuming a discount rate of $\mathrm{R}=4 \%$, the indicator determined based on relationship (8) is NPV $<0$ and it amounts to -1070259.69 , which also negates the feasibility of the investment.

$$
N P V=\sum_{i=1}^{n} \frac{C F_{1}}{(1+R)^{1}}-N, \quad l a t
$$

The investment does not turn out to be undeniably feasible until reaching $70 \%$ of funding possible to acquire via contests organised periodically with the participation of the European Union's capital, e.g. Norwegian Funds 2020. Therefore, when taking advantage of the funding, in this case $\mathrm{SPBT}=6.6$ years, which is a value lower than the maximum threshold value for which the investment is considered profitable, meaning 7 years. Interestingly, already with $50 \%$ of funding, the dynamic indicator of economic efficiency, which is the NPV, deemed more credible than the SPBT, takes on values higher than ' 0 '. To be clear, the relationship between the NPV indicator and the discount rate was determined as well, as shown in Figure 28.

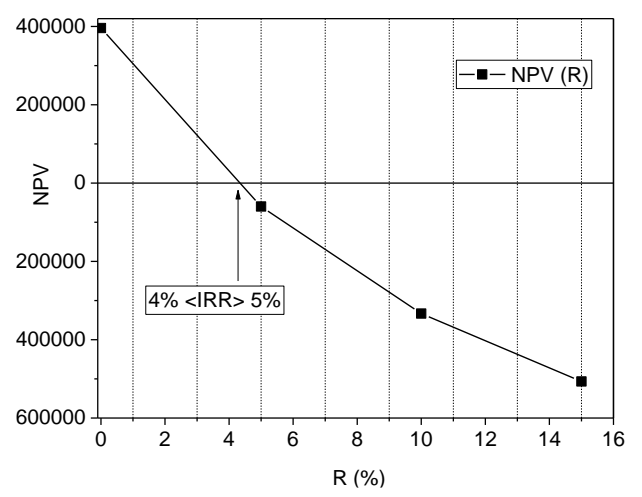

Figure 28. NPV for an investment as a function of the discount rate, $\mathrm{R}$

Figure 28 indicates that the internal rate of return IRR (for which the net present value of the evaluated option equals zero, NPV $=0$ - see relationship (9)) is between $4 \%$ and $5 \%$, and it is higher than the discount rate effective in the calculation period $\mathrm{R}=4 \%$

$$
N P V=0 \quad \sum_{i=1}^{n} \frac{C F_{1}}{(1+I R R)^{1}}=N, \text { lat }
$$

Table 8 lists the basic indicators of economic efficiency of an investment implemented in an education centre, near the geometrical centre of Europe, involving the modernisation of a gas boiler station and the assembly of a renewable heat source - a ground heat pump with a vertical heat 
exchanger supported by photovoltaic cells (the total costs include the purchase of a heat source, the drilling of boreholes, the assembly of PV cells along with gel batteries).

Table 8. Basic indicators of economic effectiveness for a sample investment

\begin{tabular}{|c|c|c|c|c|c|c|c|c|}
\hline Investment costs, EUR & 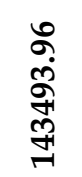 & 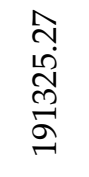 & 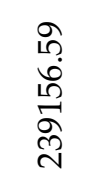 & $\begin{array}{l}8 \\
\infty \\
\infty \\
0 \\
\infty \\
\infty\end{array}$ & 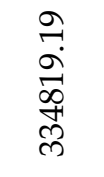 & 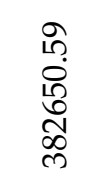 & 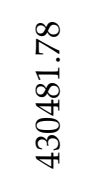 & $\begin{array}{l}\stackrel{2}{\sigma} \\
\stackrel{\infty}{\infty} \\
\infty \\
\stackrel{2}{f}\end{array}$ \\
\hline Funding, \% & 70 & 60 & 50 & 40 & 30 & 20 & 10 & 0 \\
\hline SPBT, years & 6.59 & 8.79 & 10.99 & 13.18 & 15.38 & 17.58 & 19.77 & 21.97 \\
\hline NPV & \multicolumn{3}{|c|}{$>0$} & \multicolumn{5}{|c|}{$<0$} \\
\hline
\end{tabular}

On the one hand, and for good reason, calculations are performed involving the pay-back time for expenses paid for investments related to the installation and use of renewable energy sources, which include, e.g. photovoltaic cells, often pointing at very significant savings in operating costs, as well as a reduction in harmful substances emitted into Earth's atmosphere - especially carbon dioxide and particulate matter PM - compared to the conventional manner of producing this energy.

However, these values should be related to the life cycle of a given installation, taking into account the energy, the costs and emissions associated with its components [39].

\section{Conclusions}

An analysis of the energy and economic efficiency and the ecological effect of the commissioning of a photovoltaic installation located in the geometrical centre of Europe (near Białystok, Poland) supporting a modernised central heating system based on heat pumps with a vertical ground exchanger proves that:

- in order to achieve a minimum reduction in $\mathrm{CO}_{2}$ emission of $90 \%$ (a level required to be granted funding) relative to the existing status, it is necessary to install PV cells in a number of 182 , which generates high investment costs;

- the economic potential of the utilisation of solar energy for the purpose of its conversion may reach even up to $26 \%$;

- the Simple Pay-Back Time of expenses paid for the investment SPBT $=22$ years, which in the practice of investment economics is considered infeasible;

- it is not until reaching $50 \%$ of funding that the dynamic indicator of economic efficiency NPV would take on values higher than ' 0 ';

- an investment is entirely profitable with $70 \%$ of funding, at which SPBT $<7$ years, although $\mathrm{NPV}>0$; IRR is lower than the effective and adopted rate of return amounting to $4 \%$.

Funding: 'Project financed under the programme of the Minister of Science and Higher Education called "Regional Initiative for Excellence" in the years 2019 - 2022, project no. 025/RID/2018/19, amount of funding: 12,000,000 PLN'

Conflicts of Interest: The authors declare no conflict of interest.

Nomenclature

Greeks Latter

$\lambda$ radiation wavelength

Symbols

Abbreviations (major)

$\mathrm{CO}$ carbon monoxide 


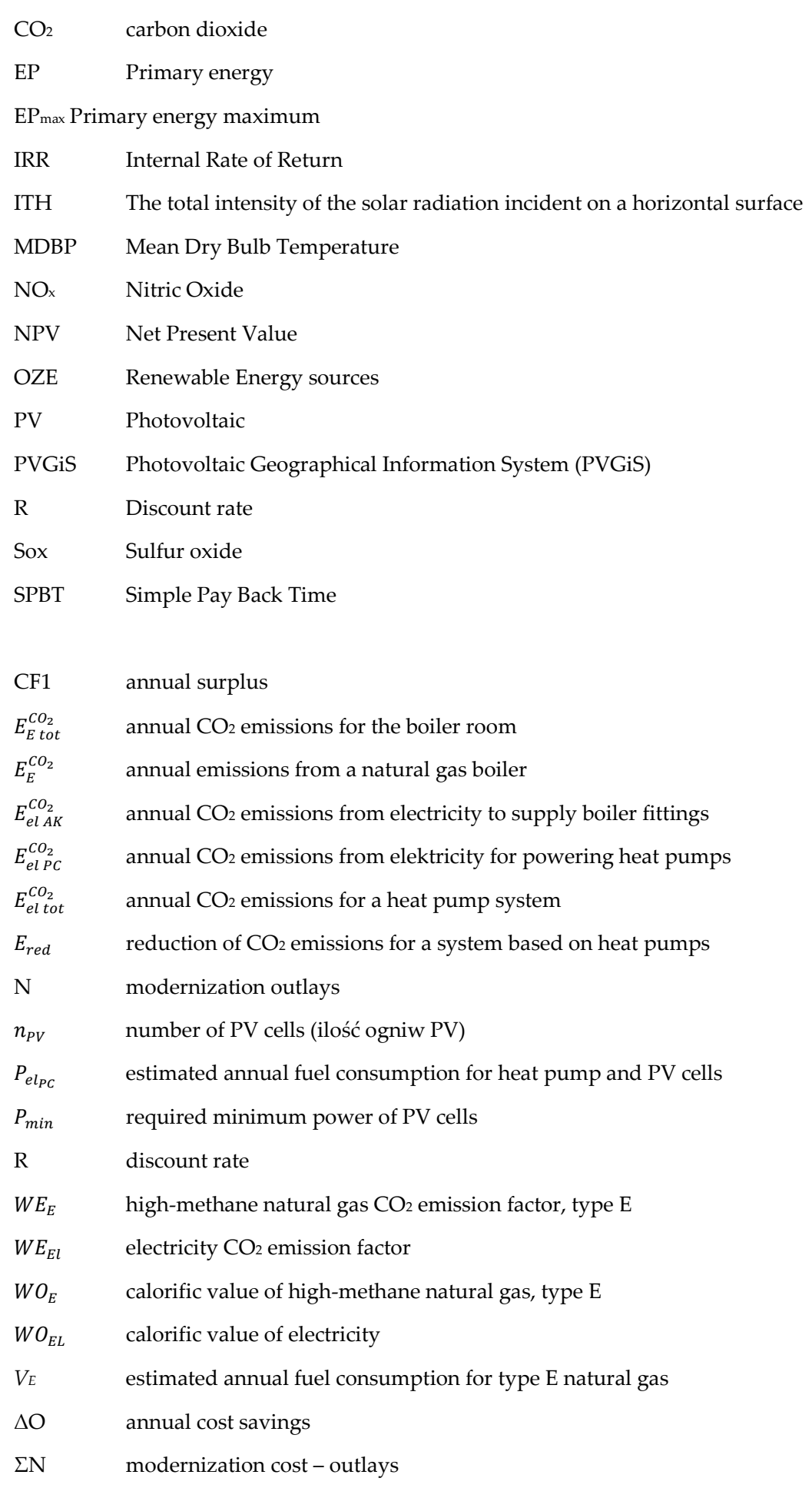

\section{References}

[1] Kabir, E.; Kumar, P.; Kumar, S.; Adelodun, A.A.; Kim, K. Solar energy: potential and future prospects. Renewable and Sustainable Energy Reviews. 2018, 82, 894-900. doi = "10.1016/j.rser.2017.09.094",

[2] Orzechowski, T.; Stokowiec, K. Quasi-stationary phase change heat transfer on a fin, The European Physical Journal Web of Conferences 2016, 114 (02086), 1-5.

[3] Renewable Energy Institute report „Photovoltaic Market in Poland” VIIIth edition, June 2020 (Instytut Energetyki Odnawialnej raport "Rynek Fotowoltaiki w Polsce". VIII edycja czerwiec 2020) 
[4] Directive (EU) 2018/844 of the European Parliament and of the Council of 30.05. 2018 amending Directive 2010/31/EU on the energy performance of buildings and Directive 2012/27/EU on energy efficiency (Text with EEA relevance).

[5] Directive 2006/32/EC of the European Parliament and of the Council of 5.04.2006 on energy end-use efficiency and energy services and repealing Council Directive 93/76/EEC.

[6] Huijben, J.C.C.M.; Podoynitsyna, K.S.; van Rijn, M.L.B; Verbong, G.P.J. A review of governmental support instruments channeling PV market growth in the Flanders region of Belgium (2006-2013). Renewable and Sustainable Energy Reviews 2016, 62, 1282-1290.

[7] Jäger-Waldau, A.; Bodis, K.; Kougias, I.; Szabo, S. The new European renewable energy directive opportunities and challenges for photovoltaics. European Commission, Joint Research Centre, Energy Efficiency and Renewables Unit, 21027, Italy, 2019 Preprint 46th IEEE PVSC, Chicago. DOI: 10.1109/PVSC40753.2019.8980694 [8] Directive 2009/28 / EC of the European Parliament and of the Council of 23 April 2009 on the promotion of the use of energy from renewable sources, amending and subsequently repealing Directives 2001/77 / EC and 2003/30 / EC

[9] Leloux, J.; Narvarte, L.; Collares-Pereira, M.; Desportes, A. Analysis of the state of the art of PV systems in Europe. PV Crops 2015 Photovoltaic Cost Reduction, Reliability, Operational performance, Prediction and Simulation; grant agreement no. 308468,

[10] Gaglia, A. G.; Lykoudis, S.; Argiriou, A. A.; Balaras, C. A.; Dialynas, E. Energy efficiency of PV panels under real outdoor conditions - An experimental assessment in Athens, Greece. Renewable Energy 2017, 101(C), $236-243$. [11] Seidel, F.; Kokhanowsky, A.; Schaepman, M. Fast and simple model for atmospheric radiative transfer. Atmospheric Measurement Techniques 2010, 3(4), 1129 -1141. doi: https://doi.org/10.5194/amt-3-1129-2010

[12] Vermote, E. F.; Tanr'e, D.; Deuz'e, J. L.; Herman, M.; Morcrette, J.-J. Second Simulation of the Satellite Signal in the Solar Spectrum, 6S: An Overview, IEEE T. Geosci. Remote, 1997, Vol. 35, 675-686,

[13] Rozanov, A.; Rozanov, V.; Buchwitz, M.; Kokhanovsky, A.; Burrows, J.; SCIATRAN 2.0 - A new radiative transfer model for geophysical applications in the 175-2400 nm spectral region, Advances in Space Research 2005, 36, 1015-1019, doi:10.1016/j.asr.2005.03.012, .

[14] Muldashev, T. Z.; Lyapustin, A. I.; Sultangazin, U. M. Spherical harmonics method in the problem of radiative transfer in the atmosphere-surface system, Journal of Quantitative Spectroscopy and Radiative Transfer 1999, 61, 393-404, doi:10.1016/S0022-4073(98)00025-9, 1999.

[15] Evans, K. F.; Stephens, G. L.; A new polarized atmospheric radiative transfer model, J. Quant. Spectrosc. Ra.Transfer 1991, 46, 413-423, doi:10.1016/0022-4073(91)90043-P, 1991.

[16] Govaerts, Y.: RTMOM V0B.10 Evaluation report, report EUM/MET/DOC/06/0502, Eumetsat 2006.

[17] Zege, E. P.; Chaikovskaya, L. New approach to the polarized radiative transfer problem, Journal of Quantitative Epectroscopy and Radiative Transfer 1996, 55, 19-31, doi:10.1016/0022-4073(95)00144-1.

[18] Ruggaber, A.; Dlugi, R.; Nakajima, T. Modelling radiation quantities and photolysis frequencies in the troposphere, Journal of Atmospheric Chemistry 1994, 18, 171-210, doi:10.1007/BF00696813

[19] Ota, Y.; Higurashi, A.; Nakajima, T.;Yokota, T. Matrix formulations of radiative transfer including the polarization effect in a coupled atmosphere-ocean system, Journal of Quantitative Spectroscopy and Radiative Transfer 2010, 111, 878-894, doi:10.1016/j.jqsrt.2009.11.021

[20] $[X V, 20]$ Stamnes, K., Tsay, S.-C., Wiscombe, W., and Jayaweera, K.: Numerically stable algorithm for discrete-ordinate-method radiative transfer in multiple scattering and emitting layered media, Applied Optics 1988, 27, 2502-2509, doi:10.1364/AO.27.002502 
[21] Berk, A.; Bernstein, L.; Robertson, D. MODTRAN: A moderate resolution model for LOWTRAN, Tech. Rep. GL-TR-89- 0122, Air Force Geophysics Lab, Hanscom AFB 1987 Massachusetts, USA.

[22] Key, J.; Schweiger, A.; Tools for atmospheric radiative transfer: Streamer and FluxNet, Computers and Geosciences 1998, 24, 443-451, doi:10.1016/S0098-3004(97)00130-1

[23] Ricchiazzi, P.; Yang, S.; Gautier, C.; Sowle, D. SBDART: A research and teaching software tool for planeparallel radiative transfer in the Earth's atmosphere, Bulletin of American Meteorological Society 1998, 79, 21012114. doi: 10.1175/1520-0477(1998)079<2101:SARATS>2.0.CO;2

[24] Mehta, M. Estimation of aerosol optical depth over Dehradun (India) using simple model for atmospheric radiative transfer in multiple scattering approximation, The Int. Arch. Photogramm. Remote Sens. and Spatial Inf. Sci. 2014, XL-8, 271-276, doi:10.5194/isprsarchives-XL-8-271-2014

[25] Hernandez-Moro J.; Martinez-Duart J.M. Analytical model for solar PV and CSP electricity costs: Present LCOE values and their future evolution, Renewable and Sustainable Energy Reviews 2013 , 20, 119-132, doi: 10.1016/j.rser.2012.11.082

[26] www.mi.gov.pl [access: 01.10.2020]

[27] Šúri, M.; Huld, T.A.; Dunlop, E.D.; Ossenbrink, H.A., Potential of solar electricity generation in the European Union member states and candidate countries. Solar Energy 2007, 81, 1295-1305, https://doi.org/10.1016/j.solener.2006.12.007

[28] https://ec.europa.eu/ [access: 01.10.2020]

[29] () 2019 The World Bank, Source: Global Solar Atlas 2.0, Solar resource data: Solargis.

[30] Ngo, X.C.; Nguyen, T.H.; Do, N.Y.; Nguyen, D.M.; Vo, D.-V.N.; Lam, S.S.; Heo, D.; Shokouhimehr, M.; Nguyen, V.-H.; Varma, R.S.; Kim, S.Y.; Le, Q.V. Grid-Connected Photovoltaic Systems with Single-Axis Sun Tracker: Case Study for Central Vietnam. Energies 2020, 13, 1457, https://doi.org/10.3390/en13061457

[31] Whang, A. J.-W.; Yang, T.-H.; Deng, Z.-H.; Chen, Y.-Y.; Tseng, W.-C.; Chou, C.-H. A Review of Daylighting System: For Prototype Systems Performance and Development. Energies 2019, 12, 2863, https://doi.org/10.3390/en12152863

[32] https://www.pvlighthouse.com.au/calculator-map [access: 01.10.2020]

[33] Bird, R.; Riordan, C.; Simple Solar Spectral Model for Direct and Diffuse Irradiance on Horizontal and Tilted Planes at the Earth's Surface for Cloudless Atmospheres, Solar Energy Research Institute 1984

[34] weather2travel.com. [access: 01.10.2020]

[35] maltaweather.com [access: 01.10.2020]

[36] Instytut Ochrony Środowiska - Państwowy Instytut Badawczy (KOBiZE). Wartości opałowe (WO) i wskaźniki emisji CO 2 (WE) w roku 2017 do raportowania w ramach Systemu Handlu Uprawnieniami do Emisji za rok 2020.

[37] Wciślik S.; Energy efficiency and economic analysis of the thermomodernization of forest lodges in the Świętokrzyski National Park. EPJ Web of Conferences 143, 2017, 02144, DOI: 10.1051/epjconf/201714302144 [38] https://re.jrc.ec.europa.eu/pvg_tools/en/tools.html [access: 01.10.2020]

[39] Piasecka, I.; Bałdowska-Witos, P.; Piotrowska, K.; Tomporowski, A. Eco-Energetical Life Cycle Assessment of Materials and Components of Photovoltaic Power Plant. Energies 2020, 13, 1385, DOI: 10.3390/en13061385 